\title{
Ireneusz Łuć
}

(Maria Curie-Skłodowska University in Lublin, Poland)

https://orcid.org/0000-0002-6388-2616

E-mail: ireneusz.luc@poczta.umcs.lublin.pl

\section{Emperor Commodus' 'Bellum desertorum'}

\author{
'Bellum desertorum' cesarza Kommodusa
}

\begin{abstract}
The article describes circumstances in which 'the war with the deserters' took place in the mid-180s AD in the Roman state. Criminal activity of Maternus, a deserter from the Roman army, who managed to surround himself with a large group of people excluded from the boundaries of legality, was transformed into an open rebellion against Commodus. Reconstruction of the circumstances outlined in the article that accompanied the formal requalifying the deserters and common outlaws as the 'enemies of Rome' would not be possible without including literary and epigraphic sources, as well as those referring to the Roman law. Only after having taken into account all the available evidence related to this topic can one provide a critical and multifaceted analysis of the history. Rejecting this approach would not allow to verify the current state of knowledge in this area, and therefore, to offer a slightly different interpretation.
\end{abstract}

Key words: Commodus, Maternus, deserters, rebellion, war, Roman army soldiers

\begin{tabular}{|c|c|c|c|c|}
\hline \multicolumn{5}{|c|}{ PUBLICATION INFO } \\
\hline$(\mathrm{IH})$ & UIMCS & * & $\begin{array}{l}\text { e-ISSN: } 2449-8467 \\
\text { ISSN: } 2082-6060\end{array}$ & OPEN $\bigcirc$ ACCESS \\
\hline \multicolumn{5}{|c|}{$\begin{array}{l}\text { THE AUTHOR'S ADDRESS: Ireneusz Łuć, the Institute of History of the Maria Curie-Skłodowska University in } \\
\text { Lublin, 4A Maria Curie-Skłodowska Square, Lublin 20-031, Poland }\end{array}$} \\
\hline \multicolumn{5}{|c|}{$\begin{array}{l}\text { SOURCE OF FUNDING: Research project funded by the resources of the National Science Centre (Poland) granted } \\
\text { on the basis of decision no. DEC-2017/25/B/HS 3/02078, titled Roman Officers in the Rank of military Tribunes } \\
\text { in the Period from Ist Century B.C. to the 3rd Century A.D. Historical-prosopographical Study. }\end{array}$} \\
\hline $\begin{array}{l}\text { SUBMITTED: } \\
2019.08 .06\end{array}$ & & $\begin{array}{l}\text { ACCEPTED: } \\
2020.05 .25\end{array}$ & $\begin{array}{l}\text { PUBLISHED ONLINE: } \\
\text { 2020.12.21 }\end{array}$ & \\
\hline \multicolumn{3}{|c|}{$\begin{array}{l}\text { WEBSITE OF THE JOURNAL: } \\
\text { https://journals.umcs.pl/rh }\end{array}$} & $\begin{array}{l}\text { EDITORIAL } \\
\text { COMMITTEE E-mail: } \\
\text { reshistorica@umcs.pl }\end{array}$ & 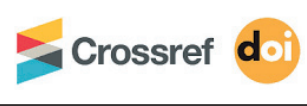 \\
\hline
\end{tabular}


Plundering attacks by Maternus, or as Brent D. Shaw prefers - Iulius Maternus ${ }^{1}$, and his outlaws (latrones), reached - from the perspective of both Commodus ${ }^{2}$ and the Roman provincial authorities in Gaul, Spain and Germania - a rank of a formal rebellion (seditio). Maternus, as a deserter from the Roman army, and his supporting companions (commilitiones), whom he organised into a great criminal division (manus latronum), were primarily only deserters and outlaws (latrones) excluded from the boundaries of the Roman law. However, the scale and audacity of their activities engendered Commodus' personal intervention, as the result of which they were recognised as 'the enemies of the Roman state' (hostes publici), and the military operation of police actions that run against them in AD 185-186/7 was reclassified into a regular 'war' - 'bellum desertorum', i.e. a war against deserters 3 . And even though the Roman commanders in the end will manage to supress Maternus' rebellion and kill him, there will appear a new continuator of criminal dealings twenty years later (AD 205-207) in Italy, who is known as Bulla Felix 4 . And in the second half of the 3rd c. AD 'the war of the deserters' in the territories of Gaul and Spain - for this cannot be completely ruled out - and the events linked to it, could have become, at least to some extent, an inspiration for new organised military rebellions, in which poor farmers, the so-called bagaudae (alias bacaudae), took part this time ${ }^{5}$. What was the reason for Maternus' phenomenon and Commodus' 'bellum desertorum' provoked by him?

\section{THE CASE OF MATERNUS, A DESERTER}

Only Herodian provides direct information on Maternus and the course of the rebellion caused by him. History of the Empire from the Death of Marcus, which in the opinion of some is supposed to be a historical romance

1 Prosopographia Imperii Romani ${ }^{1}$ [hereinafter: PIR] M 274; PIR ${ }^{2}$ M 363: 'Maternus, miles, qui militiis egressus seditionem et tumultum commovit'; A. Stein, Maternus, in: Real-Encyclopädie der klassischen Altertumswissenschaft [hereinafter: RE], vol. XIV.2, Stuttgart 1930, col. 2193; B.D. Shaw, Bandits in the Roman Empire, 'Past \& Present' 1984, 105, p. 44.

2 See: Lucius Aelius Aurelius Commodus. Cf. PIR ${ }^{1}$ A 1232; PIR ${ }^{2}$ A 1482.

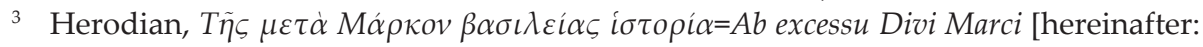
Hdn.], 1.10.1-7; 1.10.15; Historia Augusta, Vita Commodi [hereinafter: HA, Vita Commodi], 16.2; HA, Vita Pescennii Nigri, 3.3; Th. Pekáry, Seditio. Unruhen und Revolten im römischen Reich von Augustus bis Commodus, 'Ancient Society' 1987, 18, p. 145; J. Linderski, Caelum arsit and obsidione liberare: Latin Idiom and the Exploits of the Eighth Augustan Legion at the Time of Commodus, 'Zeitschrift für Papyrologie und Epigraphik' 2003, 142, p. 251.

4 Cf. PIR ${ }^{1}$ B 148; PIR ${ }^{2}$ B 173.

5 Cf. T. Grünewald, Bandits in the Roman Empire. Myth and Reality, London-New York 2004, p. 129. 
based on the personal memories of the author, recalled also the accounts of witnesses with whom he could have been in touch and the contents from other historical works which had been written earlier, in particular from the Roman History by Cassius Dio, who - what is worth noting - was staying in Rome from AD 180 where he started his senatorial career. And while Herodian's work was preserved practically in its entirety, the History by Cassius Dio unfortunately does not have all the sections of the narrative, including i.e. the parts referring to Maternus' rebellion and Commodus' war against the deserters. Importantly, it should be remembered that Herodian wrote his work around fifty years (c. AD 250) after the events. And his interest in this conflict could indirectly derive from Herodian's personal interests and could be motivated by his own status. As far as his profession was concerned, he was some minor official, holding the office in 'aerarium', or perhaps an 'apparitor Caesaris'. Although this is only a guess, Herodian probably could have been an eques. On the other hand, the Latin term 'bellum desertorum' was placed in Scriptores Historiae Augustae by the biographer of Emperor Commodus'.

As was noted by the abovementioned Herodian, Maternus had served in the Roman army before he became a deserter and a criminal. Unfortunately we do not know what formation and in which detachment he served. Academic works on this topic, which will be discussed later, also offer only some suggestions. To return to the initiated desertion, he managed to convince to it also other soldiers who were probably his comrades in arms (commilitiones). Then, with their support, after a short time he organized a unit (manus) which - apart from the deserters - included runaway slaves, poor peasants, but also criminals of different sorts. Moreover, he succeeded in significantly increasing these forces in a few years. Before deserting the military detachment in which Maternus was on active duty - which was particularly emphasised by Herodian - he was supposed to commit 'many bold acts'. And it was probably due to these 'crimes', and the fear of being punished for them, that he decided to desert the $\mathrm{army}^{7}$. Although neither in Herodian's work nor in any other source even the smallest suggestion

6 HA, Vita Commodi, 16.2: 'et ante bellum desertorum caelum arsit'; G. Alföldy, Bellum desertorum, 'Bonner Jahrbücher' 1971, 171, p. 374; F. Millar, A Study of Cassius Dio, Oxford 1964, p. 123; T.D. Barnes, The Sources of the Historia Augusta, Bruxelles 1978, pp. 81-84 and next; H. Sidebottom, The Date of the Composition of Herodian's History, 'L'antiquité classique' 1997, 66, pp. 271-275; E. Wipszycka, Herodian, in: Vademecum historyka starożytnej Grecji i Rzymu. Zródłoznawstwo starożytności klasycznej, ed. E. Wipszycka, vol. 1-2, Warszawa 2001, p. 70; T. Grünewald, op. cit., pp. 120, 123; A. Galimberti, Erodiano e Commodo. Traduzione e commento storico al primo libro della «Storia dell'Impero dopo Marco», Gottingen 2014, p. 53.

7 Cf. Hdn., Ab excessu Divi Marci, 1.10.1; H. Stephano, Thesaurus Graecae Linguae, vol. 7, Parisiis 1848-1854, p. 2270; A. Galimberti, op. cit., pp. 107-109. 
regarding Maternus' activities was preserved, it is possible to form-indirectly at least - an opinion on this matter due to the content of regulations of the Roman military criminal law. And thus, these men could be threatened with sanctions for thefts which they could have committed against both other soldiers and civilians. Moreover, Maternus and his companions would not have escaped the punishment if one of them had hurt or murdered another officer or comrade in arms. Roman soldiers of active service were not allowed i.e. to submit false reports on their allegedly heroic deeds in order to extort this way their undue rewards. Severe sanctions would certainly have not been avoided by those of whom having showed an overt disobedience to their superiors would have acted insubordinately, using physical violence towards them, and participating in a desertion, treason or rebellion ${ }^{8}$. Therefore, the 'military crime' (delictum militare), the perpetrators of which could have been 'milites Romani', was every 'other' behavior - and that was clearly emphasised by Arrius Menander - that was inconsistent with what was required of them by the generally applicable Roman military discipline (disciplina militaris). Moreover, soldiers who deserved to be punished were those who showed indolence, disobedience and laziness. And these were the forms of insubordination that Arrius Menander particularised at the turn of the 2 nd and 3rd century AD that could have posed a serious problem when it came to serving in the Roman army. The necessity of supplementing the losses in the ranks of the Roman army units - which was a result of extremely difficult Marcomannic wars - engendered a situation where in the second half of the 2 nd c. AD recruits who should not have been accepted in the army had been enlisted. This refers to i.e. freed slaves, including gladiators, and the so-called brigands-criminals (latrones) from the territories of Dalmatia and Dardania. And this was not only about a particularly low socio-legal status of these soldiers, but - what was even worse - about the lack of their proper mental preparation in order to cope with hardships and rigours of military service that were imposed on them in the Roman army. This was not changed even by the fact that they could ask to be volunteers (volones) themselves. Therefore, as was noted by Anthony Birley, groups of

8 Cf. C.E. Brand., Roman Military Law, London 1968, pp. 91-93, 101-103; G. Kuleczka, Studia nad rzymskim wojskowym prawem karnym, Poznań 1974, pp. 48-49, 52, 84-98; P. Cosme, Le châtiment des déserteurs dans l'armée romaine, 'Revue historique de droit français et étranger' 2003, 81, p. 289; I. Łuć, Disciplina militaris - charakter relacji między rzymskim dowódca a żotnierzami, in: Romanitas EChristianitas. Stanislao Płodzień (1913-1962) in memoriam, eds. A. Dębiński, S. Jóźwiak, Lublin 2008, pp. 89-92; M. Gueye, Délits et peines militaires à Rome sous la République: desertio et transfugium pendant les guerres civiles, 'Gerion' 2013, 31, pp. 222 223; I. Łuć, Kary i środki represyjne w rzymskim sadownictwie wojskowym okresu republiki, in: Przemoc w świecie starożytnym. Źródła, struktura, interpretacja, eds. D. Słapek, I. Łuć, Lublin 2017, pp. 90-91. 
runaway slaves and deserters who wandered around Gaul, Spain and Italy ${ }^{9}$ were the remnants of the Marcomannic wars. Thus, the desertion from the army of abovementioned Maternus and the soldiers accompanying him was not something accidental. This desertion (desertio) must have triggered a justified concern amongst the Roman commanders. It was for this very reason that Arrius Menander, mentioned above, gave so much attention to this crime in his treatise 'On Military Matters' (De re militari) written perhaps around AD 211 or 217. Moreover, the phenomenon of unlawful withdrawal from the detachment was also addressed in the monographs of other jurists who lived at that time, such as, amongst others, i.e. Herennius Modestinus, the author of the work 'On Punishments' (De poenis) $)^{10}$. And it is thanks to the actual conditions and regulations from the Roman military criminal law noted by these authors that there is a possibility to define in a much more precise way the crime perpetrated by Maternus and the companions from his military detachment. And thus, referring to statements by Arrius Menander, Herennius Modestinus, a deserter's name could have been earned by a Roman soldier who wandered outside of a military camp for a long time and who, after being caught, was brought back to the military camp against his will. Moreover, the prefect of the vigiles cohorts (praefectus vigilum) in Rome - and this office was held by abovementioned Herennius Modestinus - emphasised that if there were a few soldiers who had left the military unit together but who decided after some to return to the military camp, they should be punitively degraded and separated to different branches-units (lit. places). On the other hand, Arrius Menander, referring

9 Cf. HA, Vita Marci Antonini, 21.6-7; A.R. Birley, Septimius Severus. The African Emperor, London-New York 2002, p. 74.

10 Arrius Menander was an eques, lawyer, imperial advisor (consiliarius principis) during Lucius Septimus Severus' rule and a secretary at the petition department in the emperor's chancellery ('a libellis' - from AD 212 to AD 213) during Caracalla's rule (Septimius Bassianus=Marcus Aurelius Severus Antoninus). Herennius Modestinus was also of an equestrian origin. He was also a secretary at the petition department in the imperial chancellery ('a libellis' - AD 222-228). Herennius Modestinus was appointed a prefect of the vigiles cohorts in Rome ('praefectus vigilum' - AD 226-244). Cf. Digesta [hereinafter: Dig.], 4.4.11.2; 49.16.6: 'Omne delictum est militis, quod aliter, quam disciplina communis exigit, committitur: veluti segnitiae crimen vel contumaciae vel desidiae'; PIR ${ }^{2}$ A 1100; PIR ${ }^{2}$ H 112; PIR² S 446; PIR ${ }^{2} S$ 487; J. Crook, Consilium Principis: Imperial Councils and Counsellors from Augustus to Diocletian, Cambridge 1955, pp. 80, 139; no. 33, p. 151; no. 164, p. 167; A.A. Schiller, Sententiae Hadriani de re militari, in: Sein und Werden im Recht: Festgabe für Ulrich von Lübtow, ed. von W.G. Becker, Berlin 1970, pp. 297, 303; R. Syme, Fiction about Roman Jurists, in: R. Syme, Roman Papers, ed. A.R. Birley, vol. 3, Oxford 1984, pp. 1397-1398, 1406; V. Giuffrè, La letteratura "de re militari", in: V. Giuffrè, Letture e ricerche sulla "Res militaris", vol. 2, Napoli 1996, pp. 267-269; idem, Su Arrio Menandro, in: ibidem, pp. 337-376; T. Honoré, Ulpian Pioneer of Human Rights, Oxford 2002, pp. 4, 14, 17, 30, 33; R. Sablayrolles, Libertinus miles. Les cohortes de vigiles, Rome 1996, pp. 55, 77. 
to i.e. Germanicus' ordinances ('edicta Germanici Caesaris de desertoribus') from the 20s $\mathrm{AD}$ and the rescripts of Emperor Hadrian (the 130s AD) ${ }^{11}$, indicated that not all deserters should be punished in the same way. It was important to determine the course of events. However, during the conducted examinations, one should not forget also about the rank and the previous course of service of the arrested deserters, not to mention whether, in a given case of an unlawful leaving of the military unit, only one man or a few soldiers were involved, and if they could have perpetrated other unlawful acts during the desertion. Importantly, forgiveness for running away from the military detachment should include those soldiers who decided to return to their military unit of their own volition. On the other hand those who would run to the enemies of the Roman state (transfugae ad hostes), immediately became traitors (proditores) whose criminal action depleted the traits of the 'lèse-majesté crime' (crimen laesae maiestatis). Therefore, already after being arrested as the enemies of the state, those runaways were at first subjected to a punitive dismissal from the post, and then, after tortures, they were sentenced to death. The only chance for those deserters-traitors to save their lives was to catch many criminals (multos latrones) or point at other deserters who joined the enemies of the state (transfugae ad hostes) ${ }^{12}$.

As these briefly outlined characteristics of such reprehensible behaviour of the Roman army soldiers describe, the crime of desertion was not in fact a homogenous crime. It can even be assumed with a high degree of probability that Maternus and his companions from the detachment could have hoped for an act of forgiveness (venia) from the commander of their unit. However, they had to fulfil one condition, i.e. to return of their own volition to the military camp. Moreover, they could have avoided the strictest sentence since they had decided not to cross - and there is no such indication - the Roman state's border and to join the enemies of Rome. Therefore, at least in the first phase of their defection from the detachment, Maternus and the deserters accompanying him did not formally become the enemies of the Roman state (perduelles) ${ }^{13}$, which to them could actually

11 See: Nero Claudius Drusus Germanicus=Germanicus Iulius Caesar and Publius Aelius Hadrianus. Cf. PIR ${ }^{2}$ I 221; PIR² A 184.

12 Cf. Dig., 49.16.3.3: 'Desertor est, qui per prolixum tempus vagatus reducitur'; 49.16.3.9; 49.16.4.13; 49.16.5; 49.16.5.8; W. Kutzmann, Dezercja i samowolne oddalenie się w rzymskim wojskowym prawie karnym epoki pryncypatu, 'Wojskowy Przegląd Prawniczy' 1981, 36, 4, pp. 433-434.

13 Deserter who voluntarily returned to military unit after five years would have been sentenced to exile - Dig., 49.16.13.6. On the other hand, deserters who would flee to the enemies of the Roman state became traitors (proditores), which was pointed out by Publius Tarrutienus Paternus who lived at the time of Maternus' and his companions' escape. He was at the same time the author of 'On Military Matters' (De re militari). Publius 
mean not only the punitive degradation to the group of slaves and the disqualification from the Roman soldier status, but also to lead to the imposition of an extremely severe death sentence (i.e. by crucifixion, being burnt alive or fighting against wild animals in the arena) ${ }^{14}$.

Maternus, however, did not plan to return to the military camp where his detachment stationed, which his further history will unambiguously present. Due to the reasons known only to him, he did not want to ask his commander for clemency. And instead of chasing criminals (latrones) and this, in accordance with the content of the abovementioned rescript by Emperor Hadrian could have given Maternus a realistic chance to avoid the punishment for lawlessly leaving the unit - he decided together with the runaways accompanying him to organise his own 'group of criminalsdeserters'.

Although Herodian does not specify in which military unit Maternus served ${ }^{15}$ - which has also been mentioned already - there were both legions and auxiliary troops (auxilia) protecting the borders of the Roman state in the 180s AD in the areas of the provinces of Gaul (see Gallia Belgica, Lugdunensis, Aquitania, Narbonensis) and in the territories of both Germanias (Germania Inferior, Germania Superior), not to mention the Iberian Peninsula, Raetia, and Noricum. These forces were concentrated, first and foremost, in a militarised zone of provinces by the border, except for the urban cohort (cohors urbana) that stationed in Lyon (Lugudunum) ${ }^{16}$.

Tarruntenus Paternus was a senator of an equestrian background and held the office of a secretary to correspondence ('ab epistulis Latinis' - AD 170-172) and he was a prefect of the praetorium ('praefectus praetorium' - AD 177-182). Cf. PIR ${ }^{2} \mathrm{~T}$ 35; T. Honoré, op. cit., p. 4; F. Millar, The Emperor in the Roman World (31 BC-AD 337), London 1977, p. 95.

${ }^{14}$ Cf. Titus Livius, Ab Urbe condita libri, 30.43: 'de perfugis gravius quam de fugitivis consultum: nominis Latini qui erant securi percussi, Romani in crucem sublati' - more severe decisions were made regarding the fugitives who had gone to the enemy's side than the slaves who had fled to the enemy. Namely, people of Latin background were beheaded with an axe and the Roman were hanged on the crosses (201 B.C.); Dig., 48.4.1; 48.4.1.2: 'qui exercitum deservit vel privatus ad hostes perfugit'; 48.4.3; 48.19.38.1; 49.16.3.10-11; 49.16.7: 'Proditores transfugae plerumque capite puniuntur et exauctorati torquentur: nam pro hoste, non pro milite habentur'; C.E. Brand, op. cit., pp. 100-101; P. Garnsey, Social Status and Legal Privilege in the Roman Empire, Oxford 1970, pp. 126, 129, 142, 245-247; M. Hengel, Crucifixion in the Ancient World and the Folly of the Message of the Cross, Philadelphia 1977, pp. 38-40, 51; K. Amielańczyk, Crimina legitima w rzymskim prawie publicznym, Lublin 2013, pp. 26, 93, 239-240; J.G. Cook, Crucifixion in the Mediterranean World, Tübingen 2014, p. 163: 'The penalty for desertion was wild beasts or crucifixion in the Digest', pp. 215-216, 358-359, 390.

15 Cf. P. Cosme, op. cit., p. 298: 'Le témoignage d'Hérodien ne permet pas de savoir si Maternus était un légionnaire ou un auxiliaire, citoyen ou pérégrin'.

${ }^{16}$ Legions stationing in Germania: XXII Primigenia (Mogontiacum, Mainz/ Germania Superior), VIII Augusta (Argentorate-Strasbourg / Germania Superior), XXX Ulpia Victrix 
It turns out that owing to epitaphs of soldiers who served there until the 3rd century $\mathrm{AD}$, it is possible to indicate also other people whose name was Maternus. Amongst them were therefore soldiers of both active service as well as veterans. Some of them, as officers or ordinary privates, had a chance to serve in the legions, in the urban cohorts (cohortes urbanae), in auxiliary detachments (auxilia), or even in the praetorian guards (cohortes praetoriae) stationing in Rome ${ }^{17}$. Moreover, the name Maternus belonged to i.e. consuls, representatives of the rank of equites (ordo equester), Roman military commanders, representatives of the local civic authorities (ordo decurionum), as well as freedmen. Analysing the origins of this cognomen, Iiro Kajanto reached a conclusion that the cognomen

(Vetera, Xanten / Germania Inferior), and I Minervia (Bonna, Bonna/Germania Inferior). In Noricum were stationed soldiers from legion II Italica (Lauriacum, Lorch, Locica/Lotschitz), in Raetia - legio III Italica (Castra Regina/Regensburg), and in Spain - legio VII Gemina (Leon) respectively. Soldiers from the urban cohort were stationed in Lyon (cohors XIII urbana). Cf. Corpus Inscriptionum Latinarum, 16, 133=L'Année Êpigraphique, 1914, 84=L'Année Êpigraphique, 2015, 36 (Lugudunensis, Lugudunum / Lyon), AD 193 ('nomina militum qui militav[e]run[t] / in cohorte XIII urba[na] qu[ae] est / Lugduni sub Num[is]io [Clemente tri]/ buno'), [hereinafter: CIL=AE]; F. Bérard, L'armée romaine à Lyon, Rome 2015, pp. 17-38, 81. On 'auxiliares', see: J. Spaul, ALA2. The Auxiliary Cavalry Units of the Pre-Diocletianic Imperial Roman Army, Andover 1994; idem, COHORS2. The Evidence for and a Short History of the Auxiliary Infantry Units of the Imperial Roman Army, Oxford 2000; F. Gayet, Les unités auxiliaires gauloises sous le Haut-Empire Romain, 'Historia' 2006, 55, 1, pp. 64-105.

${ }^{17}$ Cf. i.e. CIL 3, 8730 (Dalmatia / Solin / Salona) the first half of the 3rd c. AD: 'Aur(elio) Materno,..., vet(erano) leg(ionis) II Ita/lic(ae) natione Noric(o)'; CIL 5, 8564 (Venetia et Histria / Regio X/ Aquileia) the first half of the 2nd c. AD: 'Matern[us] / mil(es) leg(ionis) I Miner(viae)'; CIL 12, 65 (Alpes Maritimae / Castellane / Salinae) the first half of the 2nd century AD: 'Quartin(i)o Mate/rno mil(iti) coh(ortis) XIIII / urb(anae)'; CIL 13,1833=ILS, 2126=AE 2015,873 (Gallia Lugudunensis / Lyon / Lugudunum) the first half of the 2nd c. AD: 'M(arci) Aquini Verini / optionis <c>arce/ris ex cohort(e) XIII / urban(a) Bononi/ us Gordus medi/cus castrensis / et Maccius Modes/tus et Iulius Mater/nus milites'; CIL 13, 8053=AE 1968, 395 (Germania Inferior / Bonn / Bonna) the 3rd c. AD: 'Cens(orinius) Mate[rnus n(umeri) G(ermanicianorum)]'; CIL 13, 8003a (Germania Inferior / Endenich / Bonna) the 2nd-3rd c. AD: 'Attici(us) / Maternus / m(iles) 1(egionis) I M(inerviae) P(iae) [F(idelis)]'; CIL 13, 8267a-b=AE 2014, 907 (Germania Inferior / Koln / Colonia Claudia Ara Agrippinensium) the 1st-3rd c. AD: 'C(aius) Iul(ius) Maternus / vet(eranus) ex leg(ione) I M(inervia)'; CIL 13, 7335=ILS 7096=AE 1998, 996 (Germania superior / Heddernheim / Praunheim / Nida) the 3rd c. AD: 'T(itus) Fl(avius) Sanctinus mil(es) leg(ionis) XXII / $\mathrm{P}$ (rimigeniae) [[Alexan(drianae)]] $\mathrm{P}($ iae) $\mathrm{F}$ (idelis) imm(unis) co(n)s(ularis) ,..., ex origi/ne patris T(iti) Fl(avi) Materni ve/terani coh(ortis) III praet(oriae) Piae Vindicis'; CIL 13, 7291 (Germania superior / Castellum Mattiacorum / Mainz-Kastel) the 3rd c. AD: 'Fl(avio) Iulio Materno / vet(erano) leg(ionis) XXII P(rimigeniae) P(iae) F(idelis) mi/ssus honesta missi/ one ex duplicario'; CIL 13, 6670 (Germania superior / Mainz / Mogontiacum) the 3rd c. AD: 'Pro salute / dd(ominorum) nn(ostrorum) / Sanctissimorum / Impp(eratorum) / Bono Eventu(i) mil(itum) / exercitus G(ermanici) s(uperioris) Mater/nius Perpetu(u)s mil(es) / [1] eg(ionis) [X]XII Pr(imigeniae) P(iae) F(idelis) strator'. 
could have been derived from the so-called 'familiar background', more precisely - from kinships which were strongly accentuated particularly amongst the inhabitants of Celtic areas. The adjective 'maternus' can be translated as 'maternal' and - as an individual cognomen characterising a given person - it also referred to relations of a friendly and collegial nature, not to mention gender and birth. It is worth mentioning that this Lain cognomen was popular also amongst the Roman citizens who not only came and lived in the territories of Gaul, but also amongst those who originated from the areas of the Iberian Peninsula. Geza Alföldy similarly emphasised that this cognomen was characteristic of Germanic and Gallic provinces. The name Maternus could suggest that the person who bore it was simply a 'mother's child'. And such manifestation of kinship - by all means acceptable amongst free people as is suggested by Iiro Kajanto, taking into consideration the hierarchy of the Roman society - was not appropriate for people of slave status. Therefore, this name was very rarely borne by them. Maternus as a cognomen appeared already at the beginning of the 1st century $\mathrm{AD}^{18}$.

Returning to the figure of Maternus-the deserter, unfortunately no further elements of his name (tria vel duo nomina) are known. Brent Shaw suggested that he could have borne the name Iulius as his 'nomen gentilicium'. Therefore, in his publications he referred to him as Iulius Maternus ${ }^{19}$. However, the Canadian historian did not explain on what basis he reached the conclusion that the second part of Maternus' name (nomen gentilicium) was the name Iulius. On the other hand, apart from the cognomen Maternus, the deserter must have had a family name since it was an indicator not only of belonging to a given tribe (gens) or family (familia). It also confirmed that as a 'gentilis' he was a freeborn or free person, and that he had the right i.e. to not only constitute last wills that were valid under the Roman law, but to serve in the Roman army as a citizen (civis Romanus). Unfortunately, there is no certainty as to whether Maternus, who lived in the 180s AD could even use his own praenomen. Particularly since in the case of the abovementioned praenomina

18 I. Kajanto, Latin Cognomina, Helsinki 1965, p. 18: 'In a few others, a similar influence is assumable, cf. e.g., the frequency of the cognomina obtained from terms of relationships in Celtic areas, Avitus Fraternus Maternus Paterculus Paternus Propinquus', pp. 79-80, 134, 303; G. Alföldy, Bellum desertorum, ‘Bonner Jahrbücher' 1971, 171, p. 374. Cf. L.R. Dean, A Study of Cognomina of Soldiers in the Roman Legions, Princeton 1916, pp. 74-75; S. Forier, Les anthroponymes formés sur des noms d'animaux en Gaule Narbonnaise et dans les provinces alpines, in: Noms, identités culturelles et romanisation sous le Haut-Empire, eds. M. DondinPayre, M.-Th. Raepsaet-Charlier, Bruxelles 2001, p. 508: 'Le surnom Maternus est bien attesté en Gaule', p. 533.

19 Cf. B.D. Shaw, op. cit., pp. 44-45. 
a tendency occurred in the Roman society to use it less frequently - what is clearly demonstrated by the preserved epigraphic inscriptions - from the mid-2nd century AD. Therefore, the Romans - including those from the territory of the province where Maternus was supposed to carry out his criminal and rebellious activity - having remembered him, bore two-part names (see 'duo nomina', that is nomen gentilicium+cognomina) instead of three-part names, that is 'tria nomina' 20 .

The issue of the background and the socio-legal status of Maternus has to remain in the sphere of guesses. However, in the first case it is suspected that he could come probably from the regions where he was given the opportunity to conduct his criminal and plundering dealings (Gaul-Germania-Spain?) ${ }^{21}$. On the other hand, when his name-nickname (cognomen) Maternus is concerned, it can indeed suggest connotations with broadly understood Roman civilisation and culture. And the semantics of the word Maternus (=maternal), as has already been mentioned earlier, seems to indicate that he could have had an extraordinarily strong bond with his mother. Nonetheless, any further divagations based solely on the analysis of Maternus' cognomen - for the lack of other sources - can be of little help. And making other guesses, like i.e. the one that 'only mother could be responsible for his tending and upbringing' only provides an occasion to move this argumentation to the level of statements of rather wishful and factual nature. It seems that it was in that sense that Brent Shaw, mentioned before, tried to revive the tone of arguments on Maternus, suggesting that Maternus could use the family name Iulius! However, it is worth emphasising that 'nomen gentilicium' Iulius, indicated by the Canadian historian, was in fact one of the more popular ones. And what is important, it was often borne by the inhabitants of the provinces of Noricum, Raetia, Germania (Germania Inferior, Germania Superior), Gauls and the Iberian Peninsula ${ }^{22}$. Moreover, to follow this lead - and

${ }^{20}$ Cf. B. Salway, What's in a Name? A Survey of Roman Onomastic Practice from c. 700 B.C. to A.D. 700, 'The Journal of Roman Studies' 1994, 84, pp. 130-131; L.A. Curchin, The Romanization of Central Spain: Complexity, Diversity and Change in a Provincial Hinterland, London-New York 2004, pp. 204-205.

${ }^{21}$ Cf. P. Cosme, op. cit., p. 298: 'On suppose qu'il était probablement originaire des régions où il a commis ses méfaits'.

22 Cf. J.M. Abascal Palazón, Los cognomina de parentesco en la Península Ibérica. A propósito del influjo romanizador en la onomástica, 'Lucentum' 1984, 3, pp. 220, 221-226 and next; A. Kakoschke, Die Personennamen in den zwei germanischen Provinzen. Ein Katalog. Band 1-Gentilnomina ABILIUS-VOLUSIUS, Leidorf 2006, pp. 123, 135, 154, 214, 219-220, 263, 265, 278, 293, 354; idem, Die Personennamen in den zwei germanischen Provinzen. Ein Katalog. Band 2.1- Cognomina ABAIUS - LYSMS, Leidorf 2007, pp. 93, 303; idem, Die Personennamen in den zwei germanischen Provinzen. Ein Katalog. Band 2.2- Cognomina MACCAUS - ZYASCELIS, 
obviously remembering that these are only hypothetical considerations on Maternus' potential use of the family name Iulius - it is even possible to suggest that his mother and his ancestors in general could have had ties with strongly Romanised inhabitants of the Roman colonies, which - as i.e. in Gallia Narbonensis or in Lyon (Lugdunum) - had been founded on Caesar's own initiative and then at the will of the following rulers of the Julio-Claudian dynasty (and Claudius in particular - the 40s AD). And subsequently the fact of bearing the imperial family name of Iulius/Iulia would have been the most appropriate also when one wanted to even suggest a military lineage of the inhabitants of these colonies, and thus the hypothetical ancestors of Maternus ${ }^{23}$.

However, what should be once again emphasised is that this is solely a theoretical notion which due to the lack of sources can be treated as more or less probable hypothesis. Another opinion on the social position of Maternus, his mother and his entire family has to be found in almost the same sphere. To be exact, the whole family of this famous deserter and this cannot be ruled out as it is perhaps even more likely - could be distinguished by an exceptionally low social status. As it turns out, the name Maternus was popular also amongst the Roman freedmen of both genders who lived in large numbers in the areas of the abovementioned provinces. Therefore - and I emphasise that this is only a supposition - the ancestors of Maternus-the deserter, if not his own parents, could receive, as ex-slaves after the act of manumission, not only the right to the Roman citizenship but also the privilege of keeping the names of their patrons who had previously been their owners ${ }^{24}$.

Leidorf 2008, pp. 96-97; idem, Die Personennamen in der römischen Provinz Rätien. AlphaOmega Reihe A., Bd. 252, Hildesheim-Zürich-New York 2009, pp. 220-221; idem, Die Personennamen in der römischen Provinz Gallia Belgica. Alpha-Omega Reihe A., Bd. 255, Hildesheim-Zürich-New York 2010, pp. 401-402; idem, Die Personennamen in der römischen Provinz Noricum. Alpha-Omega Reihe A., Bd. 262, Hildesheim-Zürich-New York 2012, pp. 511-512.

${ }^{23}$ Caius Iulius Caesar and Tiberius Claudius Drusus. Cf. A. Klotz, Caius Iulius Caesar, in: RE X.1 (1918) col. 186-275; PIR ${ }^{2}$ C 942; see: G. Forni, Il reclutamento delle legioni da Augusto a Diocleziano, Roma 1953, pp. 109-110; Y. Le Bohec, The Imperial Roman Army, London 2000, pp. 11-12, 77; F. Bérard, L'armée romaine à Lyon, Roma 2015, p. 52, annotation 82.

${ }^{24}$ Cf. L. Lazzaro, Esclaves et affranchis en Belgique et Germanies romaines d'après les sources épigraphiques, Paris 1993, pp. 80, 326, 375; M. Christol, C. Deneux, La latinisation de l'anthroponymie dans la cité de Nîmes à l'époque impériale (début de la seconde moitié du Ier siècle av. J.-C.-IIIer siècle ap. J.-C.): les données de la dénomination pérégrine, in: Noms, identités culturelles, pp. 51, 53; B. Rémy, La dénomination des Viennois à l'époque impériale, in: ibidem, pp. 67, 106107, 113, 117, 131-132, 161; J.-P. Bost, Onomastique et société dans la cité des Pétrucores, in: ibidem, pp. 186, 188; M. Dondin-Payre, L'onomastique dans les cités de Gaule centrale (Bituriges Cubes, Éduens, Senons, Carnutes, Turons, Parisii), in: ibidem, pp. 210, 217-218, 247-248, 250, 


\section{CIRCUMSTANCES OF THE REBELLION BREAKING OUT}

Maternus and soldiers accompanying him in the desertion of their military unit had to be aware that they could not return to their homes to seek protection and ask their relatives to help them. The obligation of handing over the deserters - just like the criminals (latrones) who were in hiding - was incumbent also on people who were related to them. If this kind of a runaway soldier came home - then despite his legal age he could still be subjected to the power of his family's superior (alieni iuris), who could be i.e. his father - he unfortunately had to be prepared for the eventuality that his 'pater familias' had a duty to 'imprison' him. And then, with the thought of handing him over, take him back to the commander of his parent military unit or, eventually, to go to headquarter of the governor of the province, at the territory of which he had been arrested ${ }^{25}$.

However, in the analysed example of Maternus and his companions, they managed to avoid not only the pursuit - if such was sent after them from the military camp - but also to safely leave behind the militarised strip of the Rhine, borderland provinces. Since, as Herodian emphasises, a place for the rogue and criminal dealings of Maternus was the region of the Celts and Iberians, i.e. the territories of Gaul, Germania and Spain. Moreover, with the general remark by the Greek author that in the initial phase they were supposed to attack the owners of farms (villae) and inhabitants of villages and larger settlements, the narrative of this remark seems to be correlated with the findings of French archaeologists who discovered traces of destructions dated to the beginning of the 180s in a few towns situated in the areas of Normandy and Aquitaine. Places of arsons and fights that had taken place there were found by them i.e. in Lillebonne, Vetus Pictavis (Vieux-Poitiers), Vendeuvre and Sanxay. And, as was suggested by Gilbert $\mathrm{Ch}$. Picard, the status of some of these townships (conciliabula - vici) would not be in conflict with the content of Herodian's statement on the criminal and plundering activities of Maternus and his companions. Moreover, Limonum (civitas Pictonum / Pictavis / Poitiers) and perhaps Mediolanum (Saintes), the first two capitals and at the same

257-258, 268, 291, 315, 317, 321-324, 336; L. Lamoine, Le pouvoir local en Gaule romaine, Clermont-Ferrand 2009, pp. 349-350; M. Navarro Caballero, J. Gorrochategui, J.M. Vallejo Ruiz, L'onomastique celtibere: de la denomination indigene a la denomination romaine, in: Les noms de personnes dans l'Empire romain. Transformations, adaptation, évolution, ed. M. DondinPayre, Bordeaux 2011, pp. 113, 115, 126, 135, annotation 189: 'Noms latins utilisés comme deuxieme idionyme dans des structures anthroponymiques pérégrines: Flauinus, Flauus, Longina, Materna, Pressus et Pullianu', pp. 147, 150, 153, 158, 163-164.

${ }_{25}$ Cf. Dig., 47.16.1; 47.16.2; 49.16.3; 49.16.13.6. 
time the largest centres of the administrative and economic nature in the Roman Aquitaine, could also be a target of their attacks. Unfortunately, as a result of damage that had taken place there, both places would lose their significance. And the status of a new capital of Aquitaine will be attained by Bordeaux (Burdigala), a port situated on the coast of the Bay of Biscay ${ }^{26}$.

Robbery (latrocinium) that Maternus and his companions started to carry out after arriving in Aquitaine, but afterwards also in other areas of Gaul, Germania and the Iberian Peninsula, engendered a situation in which the previous deserters - in the light of the Roman law - became criminals who, due to their military experience, possessions of weapon and the fact that their group was transformed into an organised gang (factio), started to be officially treated as 'latrones' or 'grassatores'. What is more, due to the aforementioned military experience, Maternus' 'criminals' could conduct each of their robbery in accordance with a previously prepared plan. From the Roman soldier, Maternus turned into a 'commander-ringleader of criminals' (dux latronum / factionum-quasi imperator?). While wanting for his companions (commilitiones) to create a harmonious and effectively cooperating collective, he had to share his spoils with them (particularly, including the stolen money) fairly. Having acted this way he managed to win over probably not only their trust but, what is more, also encourage others to join the ranks of his 'criminal detachment', and then most likely - detachments (vide manipulos factionis - manus / cohors latronum). It is highly unlikely that Maternus did not impose on the 'latrones' who were subjected to him some set of rules and guidelines of conduct - rooted in an oath made in the name of gods - which can be generally defined as a kind of a 'bandit law' (leges latronum) ${ }^{27}$. Without accepting the type of rules determining the mutual correlations and authority requirements - not to mention the elementary loyalty towards each other - they could not carry

${ }^{26}$ Cf. Hdn., Ab excessu Divi Marci, 1.10.1-2; G. Ch. Picard G., La révolte de Maternus, 'Bulletin de la Société Nationale des Antiquaires de France' 1985-1987, pp. 78-80; idem, Le vicus du Gué de Sciaux à Antigny (Vienne) en Poitou et son mini capitole, 'Bulletin de la Société Nationale des Antiquaires de France' 1992-1994, p. 315; idem, La romanisation de la Gaule problèmes et perspectives, 'Revue Archéologique', Nouvelle Série, Fasc. 2, 1993, pp. 363, 381-385; T. Grünewald, op. cit., p. 130; A. Galimberti, op. cit., p. 110.

27 Cf. Frontinus, Strategmata, 2.13.4; Dig., 48.19.11.2: 'Proposito delinquunt latrones, qui factionem habend' - brigands who organise a gang commit a crime on purpose; $\mathrm{T}$. Grünewald, op. cit., pp. 15-16 and next, 65; Ch. Fuhrmann, Policing the Roman Empire: Soldiers, Administration and Public Order, Oxford 2012, pp. 25-26. On the hierarchy system, rules of conduct, ties connecting criminal 'commilitiones' and on their 'leges latronum' see: Cicero, De officiis, 2.40; Apuleius, Metamorphoses, 4.11, 4.18: 'iubeo singulos commilitonum asportare quantum quisque poterat auri vel argenti'; 7.4-5; T. Grünewald, op. cit., pp. 6, $42-43$. 
out their criminal activity in the long term and, even more so, function within an increasingly larger community that with time started to form around Maternus. Predatory raids which ended successfully, including even those on large town centres, and the actions of opening local prisons by force during the attacks, resulted in the ranks of Maternus' 'latrones' getting continually bigger. However, apart from the freed prisoners, as Herodian emphasised, Maternus had to be joint also by others, for whom the idea of great booty and the promise of a fair participation in it were stronger than the fear of a severe punishment they could expect if they were arrested as 'latrones' 28 . Thus, he will be accompanied not only by successive deserters from the Roman army but also runaway slaves, freedmen and poor, free-born farmers (plebs rustica). As can be guessed, Maternus' forces which were numerically strengthened in this way, amounting from several hundred to a thousand or more people, could intensify the scale of criminal attacks being carried out, including the plundering and burning even of larger cities of Gaul and the Iberian Peninsula ${ }^{29}$.

Limited epigraphic evidence preserved to our times which are associated with the activity of the 'latrones' leaves no doubt as to the methods they could have used. The already mentioned term 'latrocinium' can be translated as a 'robbery'. It was simply an attack with a weapon which was usually carried out on the road, often by surprise. 'Latrones' participating in it attacked their victims by organising themselves into more or less numerous groups. And as Lucius Annaeus Seneca emphasised, 'latro' was a person who - even though he had not stained his hands with murder yet - was prepared and armed for it because he was driven by will to plunder and kill. Aelius Marcianus, a Roman jurist living in the first half of the 3rd century AD and the author of the monograph 'On Criminal Procedure in Public Law' (De publicis iudiciis), also put a particular emphasis on the

28 'Latrones' were formally denied the right to appeal when they were sentenced to death. When they were arrested, the provincial governors - guided by public interests - had a duty to punish them in accordance with a crime proven to them. However, the provincial governors - despite the official imperial instructions (mandata) and, probably, imperial regulations (constitutiones) - could freely adjudicate on the most severe sentence for the 'latrones' and without the right to clemency. Cf. Dig., 28.3.6.9; 48.13.4.2; 49.1.16.

${ }^{29}$ Cf. Hdn., Ab excessu Divi Marci, 1.10.2-3;1.10.7. E.A. Thompson, Peasant Revolts in Late Roman Gaul and Spain, 'Past\&Present' 1952, 2, pp. 11-14 and next; H. Sztajerman, Społeczeństwo zachodniorzymskie w III wieku, Warszawa 1960, pp. 158, 190, 312, 341; G. Alföldy, Historia społeczna starożytnego Rzymu, Poznań 1991, pp. 190-195, 238; A. Galimberti, op. cit., pp. 109-110; see: Eutropius, Breviarium ab Urbe condita, 9.20; Orosius, Historiarum adversum paganos, 7.25.2. In the case of Spain (Hispania citerior) there are, however, no archaeological evidence which could be linked with the attacks by Maternus' 'latrones'. Cf. J.S. Richardson, The Romans in Spain, Cambridge 1996, p. 234. 
'intention' which was meant to guide the 'latrones' organised in group to perpetrate crimes $^{30}$.

Therefore, it cannot be ruled out that also the brigands (grassatores) of Maternus - just as the 'latrones' who operated previously and subsequently in the territories of different provinces of the Roman state prepared ambushes, attacking travellers along the roads. And this could have looked like more of less the event that took place in Mauretania (Mauretania Caesarensis) with the participation of one Nonius Datus, a legionary veteran (legio III Augusta) and surveyor engineer (librator). For he was attacked by the North African 'latrones' on the road when he travelled to a place where he was meant to start building an aqueduct. Local bandits attacked Nonius Datus even though he was travelling in the company of his guards. Eventually, after a fight, the former legionary and people from his retinue managed to escape from the trap prepared by the brigands. Nevertheless, Nonius Datus was wounded ${ }^{31}$.

Owing to the inscriptions, we know of cases when other people attacked by the 'latrones' were unfortunately not so lucky. The brigands' targets were both men and women, elderly people or children, the so-called Roman civilians or military men, not to mention freeborn people or those who belonged to the class of slaves. From the brigands' perspective, the most important was always their booty, i.e. in a form of stolen money or other precious belongings and objects. Thanks to the spoils gathered in these circumstances, they could actually improve their financial situation. Therefore, the 'latrones' would murder their victims without mercy or smallest scruples, wanting to get rid of any witnesses who could testify against them in court. However, their violent conduct generated an authentic desire for revenge from the victims' relatives. Thus, as has been already mentioned, the 'latrones' received the most severe sentences. And, what

30 Cf. Seneca, De beneficiis, 5.14.2.1: 'Sic latro est, etiam antequam manus inquinet: quia ad occidendum iam armatus est et habet spoliandi atque interficiendi voluntatem'; Dig., 48.19.11.2: 'proposito delinquunt latrones, qui factionem habent'; PIR ${ }^{2}$ A 215: iuris consultus; R. Ciobanu, Vie urbaine et délinquance le cas des "latrones", in: Amoenitas urbium. Les agréments de la vie urbaine en Gaule romaine et dans les region svoisines, Caesarodunum tome XXXV-XXXVI, eds. R. Bedon, N. Dupré, Limoges 2002, pp. 276-277.

31 CIL 8, $2728=$ ILS, 5795 (Numidia, Lambaesis) the first half of the $2^{\text {nd }} \mathrm{c}$. AD: 'profectus sum et inter vias latrones sum passus; nudus saucius evasi cum meis' - I set off and was attacked by the brigands on the road; naked and wounded I run away with my (people); S. Cuomo, A Roman Engineer's Tales, 'Journal of Roman Studies' 2011, 101, pp. 141-148; A. Buonopane, Inter vias latrones sum passus (CIL VIII 2728, 18122): morire lungo le strade romane, in: Statio amoena. Sostare e vivere lungo le strade romane, eds. P. Basso, E. Zanini, Oxford 2016, pp. 42, 44: 'Nonius Datus (annotation 25), un tecnico idraulico (librator), veterano della III legio Augusta', p. 46. 
it more, Callistratus - who lived in the first half of the 2rd century AD even recommended in his monograph 'On Court Decrees (De cognitionibus) that in the cases of criminals who were particularly well-known for their cruelty, they should be punished by being hung in the places where they had plundered and murdered their victims. Implementation of this kind of punishment was meant to deter other criminals from perpetrating similar doings. And for the victims' relatives, it was probably a form of a compensation and an act of a kind of a rightful vengeance (vindicata). The death penalty for the 'latrones' was also put into effect by sentencing them to be eaten alive by wild animals during the games ${ }^{32}$.

Returning to the case of Maternus and his brigands, it was in the territories of Gallia Lugdunensis, and, more precisely, in Lyon and Autun (Augustodunum), that two inscriptions dedicated to two Roman soldiers were found. They lost their lives at the hands of the local 'latrones' and their death took place probably in the second half of the 2nd century AD, at the time when the criminal activity was carried out by Maternus and his company. Therefore, it cannot be completely ruled out that it was at their hands that the two soldiers - although in two different places and at different times - could lose their lives (a latronibus interfecti). They were one Tertius and one Ianuarius [D]osenu(s) who, as has been already mentioned, served in the Roman army. And while the commemoration of the former was taken care of by his siblings, brother Tertius Mascellio and sister Tertia Primilla, then in the case of the legionary (legio XXII Primigenia) nothing can be determined since the text of the inscription is damaged ${ }^{33}$. Abovementioned Tertius was killed when he was 33 years

32 Cf. CIL 3, 2399=ILS, 8514(Dalmatia/Solin/Salona) the 2nd-3rd c. AD: 'D(is) M(anibus) / Iul(iae) Res/tutae in/felicissi/mae inter/fectae/ annor(um) / X caus(a) or/namentor(um) Iul(ius) / Restut(us) et / Statia Puden/till(a) parent(es)'; CIL 3, 1585=CIL 3, 8021 (Dacia / Drobeta-Turnu Severin / Drobeta) the first half of the 3rd c. AD: '[...] interfecta a latro(nibus) / et vindicata / Ulcudius Baedari / et Sutta Epicadi / p(arentes) p(ientissimi) fil(io) tit(ulum) p(osuerunt)'; Dig., 48.19.28.15; PIR ${ }^{2}$ C 231: iuris consultus; R. Ardevan, Nochmals über interfecti a latronibus in Dakien, in: Studia Historica et Archaeologica in honorem Magistrae Doina Benea, Timişoara 2004, p. 24: 'Wir glauben, daß der Rechts - und Kulturstatus der Opfer keine Rolle bei ihrer Wahl spielte, und für die latrones nur ihre materielle Lage wichtig war. Solche antisozialen Taten zeigen, daß es auch in Dakien manche Sozialprobleme (Elend, Unsicherheit, Räuberei usw.) wie überall in derzeitigen römischen Welt gab'; C. Găzdac, Monetary Circulation in Dacia and the Provinces from the Middle and Lower Danube from Trajan to Constantine I (AD 106337), Cluj-Napoca 2010, pp. 145, 197; U. Ehmig, Subjektive und faktische Risiken. Votivgründe und Todesursachen in lateinischen Inschriften als Beispiele für Nachrichtenauswahl in der römischen Kaiserzeit, 'Chiron' 2013, 43, pp. 127-129 and next; A. Kolb, Communications and Mobility in the Roman Empire, in: Oxford Handbook of Roman Epigraphy, eds. C. Bruun, J. Edmondson, Oxford 2014, p. 666; A. Buonopane, op. cit., pp. 40-44.

${ }_{33}$ CIL 13, 2282 (Lugudunensis, Lyon / Lugudunum) the 2nd - 2nd-3rd c. AD: ' [... 
old, during the fifteenth year of his service, which at the same time suggests that be became a soldier when he was 18 years old. It is possible that the unit in which he was given a chance to serve was an urban cohort (cohors urbana) from Lyon. Also Ianuarius [D]osenus, although he was a soldier of the XXII Primigenia legion - and not of the XXII Deiotariana, as was suggested by Rada Varga and Annamária-Izabella Pázsint - died as a legionary during the confrontation with the criminals. Alfredo Buonopane pointed out that even though the content of both of these tomb inscriptions of the abovementioned soldiers did not allow to unambiguously state whether they could have been ambushed during the journey or had lost their lives participating in some sort of an action organised against the brigands ${ }^{34}$, both epitaphs were the only testimonies referring to a fight of the Roman soldiers against the 'latrones' and, at that, directly in the area of Gaul in the second half of the 2nd century AD. Furthermore, the reaction of the Roman authorities towards the activities of brigands, escapes of slaves and the cases of the Roman army soldiers' desertions was to organise - both before the outbreak of the 'war against the deserters' and also after it ended - military control stations (stationes) which were situated along the roads. They could take a form of field camps where the soldiers were quartered, sleeping in tents. Brick buildings which were often private properties were also suitable for this purpose. This type of military outposts were supposed to be located in all the Roman provinces. And the soldiers (milites stationarii) who had been delegated from various military units, i.e. from the legions, were directed there as staff for a fixed amount of time. Apart from ordinary privates, the so-called 'beneficiarii consularis', i.e. non-commissioned officers who were assigned for some time from their parental unit to serve as the staff of the province's governor (officium consularis), could be also found there. There were also the so-called couriers and scouts (frumentarii) amongst

Tertio ... mil(iti) ....... stip(endiorum)] / XV a latronibus [in]/terfecto qui vixi[t an]/nis XXXIII / Tertius Mascellio e[t] / Tertia Primilla fra/tri piissimo et sibi vi/vi ponendum cura/verunt [...]'; CIL 13, 2667 (Lugudunensis, Autun / Augustodunum / Haedui) the 2nd c. AD: 'Ianua[r(ius)] / [D]osenu(s?) / miles / leg(ionis) XXII [Pr(imigeniae)] / ... / a lat[r] o/[ni]bu(s) in/[terf(ectus?)]'; Inscriptions antiques. Musée de Lyon 1888-1893, vol. 3, eds. A. Allmer, P. Dissard, Lyon 1890, no. 391, pp. 390-392; L. Wierschowski, Fremde in Gallien"Gallier" in der Fremde. Die Epigraphisch Bezeugte Mobilität in von und nach Gallien vom 1. bis 3. JH.N.CHR (Texte-Übersetzungen-Kommentare), Stuttgart 2001, no. 507, p. 366; A. Kakoschke, Die Personennamen in den zwei germanischen Provinzen. Ein Katalog. Band 1-Gentilnomina ABILIUS-VOLUSIUS, p. 207.

${ }^{34}$ Cf. A. Buonopane, op. cit., pp. 43, 45; R. Varga, A. Pázsint, The reflection of personal and collective tragedies in ancient sources. 1. Personal tragedies in Roman epigraphy, 'Journal of Ancient History and Archaeology' 2018, 5, 4, p. 25. 
the 'milites stationarii'. The command over this entire subdivision which constituted the staff of a given outpost was held by the officers in the rank of centurions (centuriones regionarii). The staff of a military outpost had a function of a military police. And one of its most important tasks was the already mentioned pursuit after brigands $\mathrm{s}^{35}$.

The so-called 'prefects for defence against brigands' attacks' (praefecti arcendis latrociniis) were responsible for fighting the 'latrones' at the level of civilian police forces within the Roman colonies. They had a status of extraordinary officials ${ }^{36}$. Importantly, the senior soldiers of the praetorian guards (cohortes praetoriae) will also be involved slightly later, in the 3rd century $\mathrm{AD}$, in the role of 'agents for fighting against outlaws' (agens ad latrunculum) ${ }^{37}$.

Nevertheless, in confrontation with Maternus and his 'grassatores' this so concisely characterised Roman system of military and civil services, which functioned towards the end of the 2nd century AD and was aimed at fighting the groups of 'latrones', turned out to be ineffective. What is more, the situation in Rome where Commodus held a direct rule worked out favourably, at least at the beginning, also for the plans of the famous deserter-brigand. Starting from AD 180 when the son of Marcus Aurelius returned to the capital and when Maternus after deserting the army could also start his criminal dealings, as was suggested by Brent D.

${ }_{35}$ Cf. Dig. 11.4.1.1-2; CIL 13, 255=AE 2009, 854 (Aquitani(c)a / Saint-Bertrand-deComminges / Lugdunum Convenarum), the second half of the 2nd c. AD; CIL 13, 6127=ILS, 2401 (Germania superior / Altrip / Alta Ripa) AD 181; CIL 13, 6637 (Germania superior / Stockstadt am Main) AD 182; AE 1996, 1163 (Germania superior / Osterburken) AD 200; R. MacMullen, Soldier and Civilian in the Later Roman Empire, Cambridge 1963, pp. 56-57 and next; Ch. Fuhrmann, op. cit., pp. 11, 31-32, 34, 103 (annotation 49), 154-155, 163, 190191 and next, 201-217 and next, 222-225 and next; G. Cupcea, On Police and Administrative Duties of the Roman Military: Regionarii, 'Acta Musei Napocensis' 2016, 53, 1, pp. 151-156 and next, 161-163 and next; C. Ricci, Security in Roman Times: Rome, Italy and the Emperors, London-New York 2018, pp. 190-191 and next.

${ }^{36}$ Cf. R. Frei-Stolba, A. Bielman, H. Lieb, Recherches sur les institutions de Nyon, Augst et Avenches, in: Cités, municipes, colonies. Le processus de municipalisation en Gaule et en Germanie sous le Haut-Empire romain, eds. M. Dondin-Payre, M.-Th. Raepsaet-Charlier, Paris 1999, pp. 32-33, 43, 45-49 and next; Ch. Fuhrmann, op. cit., p. 57.

37 Cf. CIL 11, 6107=ILS, 509=AE 2004, 541 (Umbria / Regio VI / Urbino / Urvinum Mataurense) AD 246: 'Aurelius Munatianus evo/catus ex cohorte VI pr(a)eto/ria P(ia) V(indice) [[Philipp]]iana agens at / latrunculum cum militi/bus n(umero) XX classis $\{\mathrm{pr}\}$ pr(aetoriae) Raven/natis P(iae) V(indicis) Filipporum devot[i Num(ini)] / maiestatique eorum / [d] edicatam $\operatorname{Pr}($ a)esente [et Al]/[bi]no co(n)s(ulibus) VI Idus M[artias] / [Aur(elius) P]rivatus optio Aur(elius) Do[lens(?) ...] / [...]tanus Iulen(ius) Marce[llinus(?) ...] / [...]nus tes(serarius) Vibius Pau[linus(?) ...] / [...]ta sig(nifer) P(ublius) Asin(ius) A[...] / [...]tes Iuli(us) $\operatorname{Im}[\ldots] /[\ldots]$ Clemen[...] / [...] Aure(lius) Ta[...] / [...] arm(orum) Co[rnelius(?) ...] / [... A]ur(elius) Ba[...] / [...]V[]'; C. Ricci, op. cit., p. 192. 
Shaw, various types of rebellions and unrests started to break out in the territories of some of the Roman provinces at that time. Moreover, also Commodus himself could have feared for his safety since in AD 183 he became - quite literally - an assassination target, for the organisation of which was responsible Lucilla (Annia Aurelia Galeria Lucilla), his sister (AD 183). Two years later when the downfall of Sextus Tigidius Perennis, the omnipresent - as it may have seemed - prefect of the praetorium takes place, then not only his hauteur and arrogance will be revealed, but also his disloyalty and the fact of making attempts - for such charges were brought against him - to prepare a new plot against the emperor ${ }^{38}$. Thus, Commodus could feel a genuine relief when Marcus Aurelius Cleander, well-known to him, stood by his side (April-May AD 185), taking Perennis' place and becoming one of the ruler's most trusted advisers. And it was probably the awareness of threats he managed to escape unharmed that induced Commodus to accept the titles of 'Pius' (Pious) (AD 182-183) and 'Felix' (Lucky) (AD 185), which emphasises his self-creation in a suggestive way ${ }^{39}$.

To return to Maternus, it is something quite unbelievable that this criminal warlord who directed robbery dealings and was soon preparing to carry out an operation of attacking the Roman soldiers from the VIII legion 'Augusta', stationed in the camp in Argentoratum (modern Strasbourg), had to have a perfect orientation in the situation taking place at the turn of AD 184 and AD 185 not only in Rome but also in the territories of the Roman provinces. It can even be assumed that - from the perspective of his plans - the matter of a rebellion of the legionaries in Britannia in AD 184 could seem particularly intriguing to him. For it was there that, after successfully fighting off the Britons (Brittones) who attacked the Roman part of the island from the north, Ulpius Marcellus ([Lucius?] Ulpius Marcellus, legatus Augusti), a governor of the province, was to become so conflicted with the soldiers of the three legions stationing there - due to his principled attitude towards military discipline (disciplina militaris) - that the latter simply renounced

38 Events from AD 183-185 ended in death of not only Parennis but also Paternus (P. Tarrutienus Paternus), who was also a prefect of the praetorium. Cf. PIR ${ }^{2}$ T 35; PIR ${ }^{2}$ T 203.

39 Cf. HA, Vita Commodi, 6.2; PIR ${ }^{2}$ A 1481; H. Mattingly, Coins of the Roman Empire in the British Museum, vol. 4, Antonius Pius to Commodus, London 1940, pp. CLV-CLIX; B.D. Shaw, op. cit., p. 45: 'In the early 180s he deserted and, as a man of notorious daring and success in his new life as a bandit, attracted other men to join him in his operations'; O.J. Hekster, Commodus. An Emperor at the Crossroads, Amsterdam 2002, pp. 46-55 and next, 60-64; G. Migliorati, Iscrizioni per la ricostruzione storica dell'impero romano da Marco Aurelio a Commodo, Milano 2011, pp. 384-386, 435-437; A. Galimberti, op. cit., pp. 101, 107. 
their obedience. In the face of the rebellion, Ulpius Marcellus decided to leave Britannia ${ }^{40}$. What is worse, the local legionaries were to become even more enraged by the decision of Perennis who - by wanting to restore a military discipline (disciplina militaris) - appointed as their new commanders people who belonged to the rank of equites and not to senatorial class. And this was contrary - of course with small exceptions - to the practice commonly applied in the Roman army at that time (vide legati legionum senatorii). The conflict of the legionaries in Britannia with Perennis will reach its apogee at the turn of April and May AD 185 when a delegation of 1500 legionaries sent from there reaches Italy ${ }^{41}$. This would eventually lead to the abovementioned downfall of Perennis and the death sentence to his entire family. In turn, the place of this previously all-powerful prefect of the praetorium would be taken by Cleander - what has been already mentioned - who would become Commodus' most trusted adviser. And, subsequently, he would gain the position of the most influential amongst his ministers. Therefore, it would be Cleander to whom not only i.e. new commanders of the praetorian corpus would be subjected but - with the knowledge and consent of the emperor - who would acquire influence over personnel politics when appointing the most important offices in the state. It is possible that it was due to Cleander's initiative that investigation was started at that time in order to find and arrest the supporters of overthrown Perennis (vide Lucius Cornelius Felix Plotianus, legatus Pannoniae Inferioris, AD 184-185). What is more, already in the middle of AD 185 Cleander would be granted a real influence over the appointments of posts to governors of the Roman provinces. This is why, with this knowledge, Lucius Septimius Sever (legatus provinciae Lugdunensis - AD 186-188/9) would soon arrive in Gallia Lugdunensis, Publius Helvius Pertinax (legatus provinciae Britanniae AD 185-187) would reach Britannia even quicker,

40 Cf. Cassius Dio, Historia Romana, 73.8.2-6; A.R. Birley, The Fasti of Roman Britain, Oxford 1981, pp. 135-136, 139, 140-142; idem, Septimius Severus. The African Emperor, London-New York 2002, p. 74; idem, Hadrian to the Antonines, in: The Cambridge Ancient History, vol. XI, eds. A.K. Bowman et al., Cambridge 2000, p. 188.

41 Several hundred soldiers chosen from each of the three legions (1. II Augusta - Isca, 1. VI Victrix - Eburacum, 1. XX Valeria Victrix - Deva), which had stationed in Britannia, could have been delegated to these 1500 soldiers. Leaving for the continental part of the Roman state, they formed separate subunits (vexillationes), which is clearly presented by the inscription of Titus Caunius Priscus (Gargilius Quintilianus?), legatu legionis legio VI Victrix pia Fidelis / legatus Augusti. Cf. AE 1995, 231 (Roma) AD 191-192: '[praep]osito vexill(ationum) [leg(ionum) III?] [Brita]nnicar(um)?'; G. Gregori, Un nuovo senatore dell'età di Commodo?, 'Zeitschrift für Papyrologie und Epigraphik' 1995, 106, pp. 270, 273-274, 277; G. Migliorati, op. cit., pp. 201-206. 
and Decimus Clodius Albinus (legatus Germaniae Inferioris) would go to Germania Inferior ${ }^{42}$.

This is how one can characterise the context of events which were probably not just a background for the operation undertaken by Maternus. They could have even induced him to take on such a hazardous venture as an attack on the Roman military camp. Furthermore, apart from the conviction that the Roman state had descended into chaos, over which neither Commodus nor his advisers seemed to have any control, it seems that a considerable encouragement for Maternus to nevertheless take upon the risk of attacking the troops of the regular Roman army - apart from the previous successes in practising the criminal dealings - could also be the fact that more deserters and representatives of the local rural poor (peregrini-plebs rustica) joint him, which has already been mentioned a number of times. For these people the perspective of taking part in fighting with weapons in their hands and a vision of participating in getting spoils must have been significantly more tempting than everyday struggle with poverty or even destitution, and the unrelenting fiscal pressure from Rome which only intensified their condition. Therefore, Argentoratum (Argentorate) situated in the territory of Upper Germania (Germania superior) could interest Maternus and his 'latrones' - and this possibility can be by no means rejected - due to a unique nature of this town. For it was not only a military camp. Next to the legionary barracks built by the Romans on the island - situated on the River Ill, tributary of the Rhine - there was also a port and civil settlement. With the legionaries' needs in mind, it was there that different kinds of workshops and warehouses of various purposes had to be organised behind the walls of the camp. What is more, Argentoratum also played a role of a checkpoint and with time probably of a place where fees could have been charged for navigating the waters of the abovementioned river. Therefore, as can be assumed, it was not only political but also predatory dimension that Maternus and his 'latrones' pursued when they decided to attack this military and civilian station. Moreover - and this it worth emphasising - the soldiers of the VIII 'Augusta' legion who stationed in the camp probably had no commander at that time. Marcus Iuventius Caesianus (legatus legionis VIII Augustae) who will command them could in fact begin to hold this post - which was pointed out by Géza Alföldy - but only in AD $186^{43}$.

42 Cf. PIR ${ }^{2}$ C 1186; PIR ${ }^{2}$ H 73; PIR ${ }^{2}$ 487; M. Hammond, Septimius Severus, Roman Bureaucrat, 'Harvard Studies in Classical Philology' 1940, 51, p. 159, annotation 1; A.R. Birley, Septimius Severus. The African Emperor, London-New York 2002, p. 75; idem, The Fasti of Roman Britain, p. 145.

43 Cf. G. Alföldy, Die Legionslegaten der römischen Rheinarmeen, Köln 1967, no. 53, no. 55, pp. 44-47, 108; idem, Bellum desertorum, 'Bonner Jahrbücher' 1971, 171, p. 371. 
Either way, in summer (turn of July and August) of AD 185, Maternus decided to attack Argentoratum although, what should be once again emphasised, the camp was situated rather on a riven island and was already surrounded at that time by a moat and a stone wall. Apart from properly strengthened gates, towers which were located in the corners of the wall were additional defensive valour of these fortifications ${ }^{44}$.

Due to the inscription of Caius Vesonius Vindex we know that as a military tribune he served in the VIII 'Augusta' legion. And what is more, he also had a chance to participate in its 'liberation' when a 'new siege' took place, implicitly: of the legion in Argentoratum camp ${ }^{45}$. The term 'siege' (obsidio), used in the text of honorary inscription which was dedicated to the abovementioned military tribune did not appear only for a rhetoric effect in order to dramatise this entire event. Evidence of destruction in the camp in Argentoratum - dated to the period between AD 180 and AD 190 - were found by French archaeologists ${ }^{46}$. Therefore, from the perspective of the analysed attacks by Maternus' 'latrones', this can mean only one thing: they managed to break through the natural obstacle in the form of the River Ill, get directly under the walls of the camp of the VIII 'Augusta' legion, and begin its assault.

Returning once again to the inscription of Caius Vesonius Vindex and the term 'nova' used in it, this did not have to mean only 'the recent siege' (nova obsidione), as Jerzy Linderski tried to prove in a very interesting and meticulous way. However, what is extremely important, the term 'nova obsidione' translated as 'new' or 'siege of a new type' would articulately refer to 'the new attackers', i.e. deserters, criminals, and rebellious inhabitants of the provinces, with whom Caius Vesonius Vindex had a chance to fight $\mathrm{t}^{47}$. In other words, one might deal here with the 'latrones'

${ }_{4}$ Cf. J.-J. Hatt, Le passé romain de Strasbourg, 'Gallia' 1949, 7, 2, pp. 164, 167-170, 178180; idem, Argentorate. Strasbourg, Lyon 1993, pp. 15-16, 18-23, 33.

45 CIL 11, 6053=AE 2003, 598 (Umbria / Regio IV / Urbino / Urvinum Mataurense) AD 186-192: 'C(aio) Vesnio C(ai) f(ilio) Stel(latina tribu) Vindici populus Urvin(atium) / ,..., tribun(o) milit(um) leg(ionis) VIII Aug(ustae) quo militante / cum liberata esset nova obsidione / legio Pia Fidelis / Constans / «Commoda» cognominata est ipse ut devotissimus / Imp(eratori) «Commodo Aug(usto) Pio Felici» oblato honore quaestor/ designatus est annorum XXIII/'. See: PIR ${ }^{2}$ V 435; A. Donati, Epigrafia romana. La comunicazione nell'antichità, Il Mulino 2002, pp. 40-42.

${ }^{46}$ Cf. O. Richier, Centuriones ad Rhenum. Les centurions légionnaires des armées romaines $d u$ Rhin, Paris 2004, p. 381: 'Les destructions partielles du camp d'Argentorare, que l'archéologie a révélées pour les années 180-190, témoignent des combats qui s'y déroulèrent et que les nouvelles épithètes de la VIIIe Augusta relient à une tentative d'usurpation manquée, très certainement celle de Maternus'.

${ }^{47}$ Cf. M. Reddé, Legio VIII Augusta, in: Les légions de Rome sous le Haut-Empire, ed. Y. Le Bohec, Lyon 2000, p. 125; J. Linderski, op. cit., p. 244; A. Galimberti, op. cit., pp. 108-109. 
and Maternus who - under the Roman law and at the time the attack began - did not have the legal status of the 'enemies of Rome' (hostes publici) ${ }^{48}$.

Already mentioned fact of liberating the legion VIII 'Augusta' (cum liberta esset nova obsidione legio) and, at the same time, Argentoratum, i.e. the camp and settlement - and this could have been done probably by the legionaries of that unit alone - meant only one thing for Maternus and the 'latrones': defeat and retreat from the island. Moreover, soldiers from the VIII 'Augusta' legion received from Commodus an award for bravery, a right for the legion to be honoured with titles: 'Pia', 'Fidelis', 'Constans', and 'Commonda', which was an unambiguous reference to his imperial titles. This way the abovementioned ruler tried to distinguish the legionaries. And this kind of privilege, for the participation in fighting against Maternus' 'latrones' will be bestowed also on other Roman military units. As early as the following year - and then probably every year (on 12 August AD 186-187?) - soldiers from the abovementioned VIII 'Augusta' legion will not only enjoy the titles in remembrance of the battle but, what is very likely, circumstantial money awards (donativa), granted to them at that time by Commodus ${ }^{49}$.

For Maternus and the 'latrones' the result of the attack which ended in failure was undoubtedly a change in legal qualifications of their previous criminal activity. The siege of the camp of the VIII 'Augusta' legion, although unsuccessful for them, was no longer treated by Commodus and his advisers only as another predatory excess of some Maternus and his companions. With their behaviour they had crossed the proverbial boundary which separated 'ordinary brigands' and 'thieves' from 'traitors' and the 'enemies of the Roman state'. By committing the attack on the garrison in Argentoratum, Maternus and his companions, became - within several hours and in the light of the Roman law - rebels who disobeyed Commodus. At the same time they incited a rebellion against the Roman state (seditio). Therefore, when the news on the attack by Maternus and his 'latrones' reached Rome - most likely in the form of letters and official protocol in which the entire event had been described in the chancellery of the VIII 'Augusta' legion - which could have taken place already in August $\mathrm{AD} 185^{50}$, the Senate, probably at the request of Commodus, adopted

${ }^{48}$ Cf. Dig., 50.16.118: “Hostes' hi sunt, qui nobis aut quibus nos publice bellum decrevimus: ceteri 'latrones' aut 'praedones' sunt' - 'The enemies' are those who have publicly declared war against us or those on whom we have declared war: others are 'brigands' and 'pirates'.

${ }^{49}$ Cf. A. Galimberti, op. cit., pp. 108-109.

50 Soldiers from the legion VIII 'Augusta' - who could have stationed in Rome (numerus frumentariorum) - carried out the tasks of couriers delivering correspondence between the 
a resolution recognising Maternus and his 'latrones' as the 'enemies of the Roman state' (hostes publici). After the act of declaring war, the operations carried out against them became reclassified from those of typically police nature to a regular 'war with the deserters' (bellum desertorum) ${ }^{51}$.

Therefore, in the following months of AD 185 and AD 186 coordinated military activities aimed at Maternus and his 'deserters' were probably taking place ${ }^{52}$, in which not only the soldiers of the VIII 'Augusta' legion, commanded by Marcus Iuventius Caesianus (legatus legionis VIII Augustae), but also legionaries from other units were partaking. For participating in this operation Commodus would grant these legions the right to titles which referred to:'Pia' (pious)-'Fidelis' (loyal)-Commoda(ae/ ianae) (of Commodus). Amongst these units was also the XXII 'Primigenia' legion which stationed in Mainz (Moguntiacum). It was commanded by Quintus Aurelius Polus Terentianus (legatus legionis XXII Pr(imigeniae) $\mathrm{P}($ iae) $\mathrm{F}$ (idelis)). From this legion came Ianuarius [D]osenu(s), who has already been mentioned, and who died at the hands of the 'latrones'. Amongst other soldiers and officers participating in the operation against the 'deserters' were also T(itus) Fl(avius) Vitalis and Sextilius P[...]. They both served as centurions. What is more, they could have been also joint by the legionaries from the legion I 'Minervia' which stationed in Bonn (Bonna). Amongst the soldiers of the latter unit one Vettius Rufinus (V[e] ttius Rufi/nus), as a centurion, commanded a subdivision of the military police (statores) from two legions. Melius Gervinus and Titus Glavius Hospitalis who represented this unit were also of a rank of centurions. Furthermore, soldiers from the XXX legion 'Ulpia Victrix' stationing in

imperial praetorium in Rome and the chancellery of the parent legion in Argentoratum. See: CIL 6, 3354 (Roma): 'D(is) M(anibus) / C(ai) Melloni / Vicani / fru(mentarii) leg(ionis) VIII / Aug(ustae) P(iae) C(onstantis) C(ommodae) Iul(ius) / Emeritus h(eres) f(ecit)'. Cf. I. Łuć, Boni et mali milites Romani. Relacje między żotnierzami wojsk rzymskich w okresie Wczesnego Cesarstwa, Kraków 2010, pp. 258-259.

${ }^{51}$ Cf. Hdn., Ab excessu Divi Marci, 1.10.1-2; J. Linderski, op. cit., p. 251; see: I. Łuć, Wojna Gn. Pompejusza z piratami, in: Gnejusz Pompejusz Wielki (106-48 przed Chrystusem) / Wybitni Rzymianie czasów schyłku Republiki, ed. N. Rogosz, Katowice 2018, pp. 14-15; idem, Archeologia wojny na wyniszczenie. Wojna galilejska Wespazjana i Tytusa (maj-listopad 67 roku naszej ery), 'Ethos', 2018, 31, 2 (122) 'Krzywda', pp. 236-238.

52 Perhaps military activities against Maternus' 'latrones' were referred to as 'expeditio Germanica tertia'. However, Commodus did not take part in this expedition. Cf. i.e. CIL 5, 2155 (Venetia et Histria / Regio X / Altinum); HA, Vita Commodi 12.8; D. Kienast, Römische Kaisertabelle, Darmstadt 1990, p. 148; V. Rosenberger, Bella et expeditiones. Die antike Terminologie der Kriege Roms, Stuttgart 1992, p. 110; O.J. Hekster, op. cit., p. 66, annotation 148; A. Molinier-Arbo, Les documents d'archives dans la Vita Commodi: degré zéro de l'histoire ou fiction?, 'Dialogues d'histoire ancienne', Supplément no. 4.1, 2010, pp. 106-107; G. Migliorati, op. cit., p. 227. 
Xanten could probably also have participated in fighting Maternus and his 'deserters'. Importantly, it cannot be ruled out that these 1500 legionaries from Britannia who came over to Italy in order to deal with Perennis could also be sent to the operation of suppressing the rebellion of Maternus' 'deserters'. Finally, the task of fighting against them (or quite literally: capturing them) in the territories of Gaul (Lugdunensis, Aquitania) was also given to Caius Pescennius Niger, whom Commodus had appointed (the turn of AD 186 and AD 187) as an independent commander (legatus contra rebelles) of this operation. More importantly, as it turned out, he succeeded in fulfilling his task. Perhaps Tertius mentioned before, who was killed by the 'latrones' near Lyon, could have been somehow linked as a soldier with the operation commanded by Perscennius Niger ${ }^{53}$. Supervision over war operation against Maternus' deserters in Upper Germania - but perhaps also in Raetia - was held by Marcus Helvius [Cle] mens Dextrianus (legatus Augusti pro praetorae provinciae Germaniae superioris). On the other hand, a unit assigned from the legion VII 'Gemina Felix', stationing in León, could have operated in the Iberian Peninsula, in the strip of the Pyrenees, fighting the 'deserters'. This subdivision was commanded by a centurion, Iunius Victor ${ }^{54}$.

53 HA, Vita Pescennii Nigri 3.3-4: 'nam ipse missus erat ad comprehendendos desertores, qui innumeri Gallias tunc vexabant'; CIL 13, 6558 (Germania superior / Jagsthausen), AD 186: 'T(itus) Fl(avius) / Vitalis Ael(ia) Aug(usta) / mil(es) leg(ionis) XXII $\mathrm{P}$ (rimigeniae) $\mathrm{P}$ (iae) F(idelis) / b(ene)f(iciarius) co(n)s(ularis)'; CIL 13, 6728=AE 1899, 190 (Germania superior / Mainz / Mogontiacum) AD 192: '[leg(ionis) X]XII Pr(imigeniae) P(iae) [F(idelis) [[[Com[modianae(?)]]]'; CIL 13, 7325; CIL 13, 12405,2 (Germania interior / Katwijk aan Zee / Lugdunum) AD 180 to AD 192: 'Leg(io) XXX / C(onstans) C(ommoda) P(ia) F(idelis)'; AE 1935, 100 (Germania interior / Koln - Deutz / Divitia / Colonia Claudia Ara Agrippinensium) AD 171 to AD 192: 'V[e]ttius Rufi/nus I (centurio) leg(ionis) I M(inerviae) / [[[P(iae)] F(idelis) C(ommodianae) cu]]ram / agens strato/rum leg(ionum) I M(inerviae) et / XXX U(lpiae) V(ictricis) et pedi/tum singulari/um Alli Fusci / co(n)s(ularis)'; PIR ${ }^{2}$ A 1184; PIR 254; G. Alföldy, Die Legionslegaten der römischen Rheinarmeen, Köln 1967, no. 53, no. 55, pp. 44-47, 108; idem, Bellum desertorum, 'Bonner Jahrbücher' 1971, 171, pp. 369, 371373; I. Piso, Fasti Provinciae Dacie I. Die senatorischen Amtsträger, 1993, pp. 140-141; idem, Fasti Provinciae Dacie II. Die ritterlichen Amtsträger, Bonn 2013, pp. 60-61; O. Richier, op. cit., no. 294, no. 318, pp. 330, 333, 347-348, 362-364, 378, 380-381; A.R. Birley, The Roman Government of Britain, Oxford 2005, pp. 169, 262; G. Migliorati, op. cit., pp. 165-166; M. Reuter, Legio XXX Ulpia Victrix. Ihre Geschichte, ihre Soldaten, ihre Denkmäler, Darmstadt/ Mainz 2012, p. 170, see: annotation 33.

54 Cf. CIL 13, 11757=AE 1912, 122 (Germania superior / Öhringen / Vicus Aurelius) AD 187: ' $[\mathrm{N}] \mathrm{ym}[\mathrm{p}]$ his / pro salute et $\mathrm{Vi} /$ ctoria $\operatorname{Imp}$ (eratoris) $[[\mathrm{C}[\mathrm{o}] \mathrm{m}]] /[[$ modi]] Antonini / Aug(usti) Pii [[Felici[s]]] ius/su Clementis / Dextriani leg(ati) / Aug(usti) pr(o) pr(aetore) quod / aqua non esse[t] / induxit per Iul(ium) De/[m]etrianum I (centurionem) leg(ionis) V[III] / Aug(ustae) P(iae) F(idelis) C(onstantis) [[Commod(ianae)]] / per pedes / Crispino et Aeliano co(n)s(ulibus)'; CIL 2, 6183 (Hispania citerior / Empuries / Ampurias / L'Escala / La Escala / Emporiae) the 2nd c. AD: 'I(ovi) O(ptimo) M(aximo) / vexillatio / [1] eg(ionis) 
And thus, a mass offensive of the Roman troops, carried out simultaneously in the territories of a few provinces, let to encircling and breaking up the largest groups of the deserters. The heaviest fights could perhaps end already in August of AD 186. In the following months that same year, practically until spring of AD 187, the Romans will pursue Maternus and his remaining companions. In the case of the 'deserters' who had been taken prisoners, their sentencing started already in August AD 186. For a proper conduct of judicature, is was a key matter to separate the authentic 'deserters' from people who had been arrested randomly by soldiers. And then in the group of the 'deserters', it was important to separate the Romans from all those who did not have the Roman citizenship. The task of verifying the socio-judicial status of the prisoners could most likely be given to the officers of lower ranks, deployed by the supervisors who had the right to condemn people to death (ius gladii). After making the division into the so-called 'nostri', i.e. the Roman citizens, and 'reliqui' - 'peregrine', and 'dediticii', who came from the provinces, the courts of law could be started, during which the Romans were judged in accordance with 'lex de rapina', i.e. regulations regarding plunder with the use of force (rapina) and robbery/banditry (latrocinium). In relation to people of a different status - exempting, of course, those who were proven to be actively involved in violence - financial penalties were imposed ${ }^{55}$.

As Herodian emphasised, Maternus realised that a fight with the regular Roman army - which was sent against him on such a large scale - did not promise even the slightest chances of success. Therefore, he decided to leave his people behind in the provincial territories and carry out an attack on Commodus in Rome. In order to avoid the pursuit of the Roman soldiers who hunted down the 'deserters', Maternus set off with only a small detachment of companions. Heading south, he travelled through sparsely populated territories, using rarely frequented routes and trails. Having reached the strip of the Alps and having crossed them, Maternus entered Italy - which took place probably at the beginning of

VII G(eminae) F(elicis) / [s]ub cura / [I]uni Victo/ris I (centurionis) leg(ionis) ei/[u]sdem ob na/[ta]lem Aquilae'. Cf. PIR ${ }^{2}$ H 70; G. Alföldy, Bellum desertorum, p. 373; O.J. Hekster, op. cit., p. 66; O. Richier, op. cit., no. 329, 377-378; Z. Varhelyi, The Religion of Senators in the Roman Empire. Power and the Beyond, Cambridge 2010, p. 141.

${ }_{55}$ Cf. HA, Vita Commodi, 13.5-8; AE 1959, 141 (Germania superior / Rottweil / Arae Flaviae) AD 186 - according to the editors of 'L'Année Épigraphique': 'Il est important de relever le comportement du pouvoir après les événements: les citoyens Romains qui ont participé à la revolte seront cités en justice de rapina et aussi de latrocinio. Pour les noncitoyens, ils seront condamnés à des amendes en numéraire'. A different interpretation of the content of the so-called plaque of Rottweil see: AE 1981, 691. Cf. A. Galimberti, op. cit., p. 108; see: Dig., 10.2.4.2; 48.19.27.2. 
AD 187 - and realising that the guard by Commodus was held by the praetorians protecting the emperor in this way from assassination, he decided that the most favourable day to attack him was the so-called 'day of rejoicing/joy' (Hilaria), which took place each year on the 25th of March as one of the ceremonies in honour of goddess Magna Mater and Attis. It was on that day, on the occasion of Attis' rebirth that the procession was organised, in which objects symbolising wealth were carried in front of the goddess' statue. Participants of the parade dressed up, putting masks on their faces. As Herodian emphasised, they could pretent to be people they were not in reality. Maternus decided that on the day of this celebration he would dress up for the procession as one of the praetorians. And then, together with his companions, after mingled with the crown 'hastiferi', he could not only mislead the praetorian guards but, getting closer to Commodus by surprise, kill him. The plan of this assassination was, however, revealed. Maternus was betrayed by a few of his companions who did not want their commander to become the ruler of the Roman state after Commodus' overthrow. A few days before the commencement of the celebrations in honour of Magna Mater, Maternus and his people were arrested. It was on the 25th of March AD 187 when the celebration for the 'day of joy' (Hilaria) started that Maternus was probably beheaded and his companions were to be deservedly punished. After making sacrifices to the goddess and vowing the votive gifts, Commodus, in turn, led the procession in her honour in a joyful mood. And the people of Rome who participated in the celebration were eagerly rejoicing at the ruler's rescue. In turn, the text of the Athenian inscription dated to AD 187 has an annotation about Commodus' military victory, and more precisely as is suggested by James H. Oliver - about the final victory in 'bellum desertorum' in Gaul. Information on this event could reach Athens in May or June AD 187. The concluding end to operations against the 'deserters' could have taken place perhaps at the beginning of AD $188^{56}$.

$* * * * * *$

Even though from the Roman perspective the 'war with the deserters' ended in victory, the near future proved that this success greatly strengthen neither Commodus, in terms of his position in the country, nor it solved

${ }^{56}$ Hdn., Ab excessu Divi Marci, 1.10.3-7; J.H. Oliver, Three Attic Inscriptions concerning the Emperor Commodus, 'The American Journal of Philology' 1950, 71, 2, pp. 172-174; A. Galimberti, op. cit., pp. 113-116. 
the problems, the distinctive catalyst of which were the events provoked by Maternus who had run from the Roman army. He is still a mystery if only due to a relatively small amount of sources which refer to him directly. On the other hand, there is quite enough evidence linked to both Maternus and 'bellum desertorum' to consider the extreme and unfounded opinions which generally undermine the very existence of Maternus or the significance of the 'war with the deserters': could this entire event be in fact something so important, or perhaps quite the opposite: was it supposed to be a minor incident?

It seems that the best answer for such observations is the matter of the attack on Argentoratum where the soldiers from the VIII 'Augusta' legion stationed. The operation of capturing such a facility had to be previously prepared by someone like Maternus, at the same time remembering about the unique assets of this place since the legion headquarter was situated on the river island. What is more, the very fact of carrying out this operation required to gather forces amounting not to several hundred but at least several thousands of people capable to fight, not to mention weapons and appropriate equipment. Thus, contrary to all appearances, Maternus - and it must be admitted that he even could have been a charismatic commander who skilfully combined personal talents with military experience could effectively lead larger groups of people. Therefore, contrary to all appearances, he could have been a person 'of flesh and blood', and not only a literary 'topos'. Even more so if one is to consider the objectives Maternus set for himself. Then it is even possible to see that he did not have much in common with what is, from a current perspective, attributed to the socalled romantic brigands-heroes or even those fighting for the fate of the oppressed and 'revolutionaries'. On the contrary, Maternus was far from these aspirations and everything he undertook seems to rather indicate that, if anything, he could have belonged to people who had their feet placed firmly on the ground. This characteristic seems to be excellently illustrated by his plan to leave the provinces - and therefore, his own people - and go directly to Rome. It is quite certain that the unsuccessful expedition to Argentoratum prompted Maternus to undertake such steps because the entire operation presented in a brutal way the weakness of the 'latrones' in confrontation with the regular detachments of the Roman army. In the face of the reaction of Commodus and his advisors - and it has to be strongly emphasised that for them the 'war with the deserters' could appear, in case of a quick and convincing victory, as an ideal opportunity to gain as much as possible in terms of politics and image - Maternus had nothing left but to follow the 'path' previously chosen by Lucilla and Perennis. This meant nothing more but an attempt to assassinate the emperor in Rome. 
In terms of the socio-legal background, the 'latrones' who became members of Maternus' gangs - what had already been accentuated a few times - were evidently not only just deserters. And thus, due to the prism of status and origins of these men, Commodus' 'bellum desertorum' was in reality a 'war with brigands'. The only common denominator that linked all Maternus' 'latrones' was obviously the willingness to improve their material position ${ }^{57}$. However, the criminal activity carried out by them was by no means associated with the acts of taking over the land by force, occupying estates that were privately owned, or seizing towns for a longer period of time. Plundering activity conducted by Maternus and his companions was also not intended to awaken any ethnic or national awareness. The political dimension that appeared in their activity - from the middle of AD 185 - was generally linked with opposing the authority held by Commodus in the Roman state. Additionally, for the Roman authorities the operation of breaking and pacifying the groups of Maternus' 'deserters' also did not solve the problem of the brigands' plundering activities in a categorical way, which was soon to be revealed. Probably not all the 'deserters' were captured. In the place of those imprisoned or killed, new ones started to appear, which seems to excellently illustrate the content of the inscription from AD 194 made already during the rule of Septimius Severus as a new emperor of the Roman state. It was dedicated to Campanus of Spain, from New Carthage (Iulia Nova Carthago), and Silvanus, who 'were killed in this place by criminals' 58 .

On the other hand, referring to the impression that Maternus and his 'deserters' could have made on the Roman society, they undoubtedly were an inspiration for all the other 'latrones', i.e. Bulla Felix, who also managed to organise a group of 600 people and succeeded at plundering Italy for two years (AD 203-205) ${ }^{59}$. However, neither Bulla Felix nor any other 'latrones' managed later to engender a situation in which their criminal activity once again became 'casus belli'.

(translated by Anna Miączewska)

57 Cf. H. Sztajerman, op. cit., pp. 312-312

58 Cf. CIL 13, 259 (Aquitania, Valcabrere / Lugdunum Convenarum) 28 May AD 194: 'Canpan[us] / [nat(ione)] H(ispanus) Iul(ia) Nov(a) [Karth(agine) et] / Silvanus a [latro]/ nibus hi[c inte]/rfecti V [kal(endas) Iun(ias) Imp(eratore) [L(ucio) Sept(imio)] / Sev(ero) co(n)s(ule) I[I] / Silvan[us et] / Martin[us] p(onendum) c(uraverunt)'; S. Esmonde-Cleary, Rome in the Pyrenees. Lugdunum and the Convenae from the first century B.C. to the seventh century A.D., London-New York 2008, p. 86.

59 Cassius Dio, Historia Romana, 72.10.1-10; T. Grünewald, op. cit., pp. 110-113 and next. 


\section{REFERENCES}

\section{Primary sources}

/narrative, legal, epigraphic/

Ammianus Marcellinus, Res gestae, comp. and transl. by É. Galletier: Ammien Marcellin, Histoire, I-VI, Collection des Universités de France. Série Latine, Paris 1978-1999 / Ammianus Marcellinus, Dzieje rzymskie, transl. I. Lewandowski, vol. 1-2, Warszawa 2001-2002.

Cassius Dio Cocceianus, Historia Romana = Dio's Roman History, ed. E. Cary, 9 vols., LCL, London 1914.

Apuleius, Metamorphoses / The Golden Ass: Being the Metamorphoses of Lucius Apuleius, transl. W. Adlington, revised S. Gaselee, LCL, London 1922 / Apuleius, Metamorphoses, transl. J. A. Hnason, LCL, Harvard 1989.

Cicero Marcus Tullius, De Officiis, ed. and transl. by W. Miller, LCL, London 1913.

Digesta, ed. Th. Mommsen, Berolini 1905 / Digesta Iustiniani. Digesta Justyniańskie, Księgi 1-50, vol. 1-7, ed. T. Palmirski, Kraków 2013-2017.

Eutropius, Breviarium ab Urbe condita, eds. D.C.G. Baumgarten-Crusius, H.R. Dietsch, Leipzig 1882.

Donati A., Epigrafia romana. La comunicazione nell'antichità, Il Mulino 2002.

Herodianus, Ab excessu divi Marci libri octo, ed. L. Mendelssohn, Lipsiae 1883.

Isidorus Hispalensis, Etymologiarum sive Originom libri XX, ed. W.M. Lindsay, vol. 1, Oxonii 1911.

Inscriptions antiques. Musée de Lyon 1888-1893, eds. A. Allmer, P. Dissard, vol. 3, Lyon 1890.

Kakoschke A., Die Personennamen in den zwei germanischen Provinzen. Ein Katalog. Band 1-Gentilnomina ABILIUS - VOLUSIUS, Leidorf 2006.

Kakoschke A., Die Personennamen in den zwei germanischen Provinzen. Ein Katalog. Band 2.1Cognomina ABAIUS - LYSMS, Leidorf 2007.

Kakoschke A., Die Personennamen in den zwei germanischen Provinzen. Ein Katalog. Band 2.2Cognomina MACCAUS - ZYASCELIS, Leidorf 2008.

Kakoschke A., Die Personennamen in der römischen Provinz Rätien. Alpha-Omega Reihe A., Bd. 252, Hildesheim-Zürich-New York 2009.

Kakoschke A., Die Personennamen in der römischen Provinz Gallia Belgica. Alpha-Omega Reihe A., Bd. 255, Hildesheim-Zürich-New York 2010.

Kakoschke A., Die Personennamen in der römischen Provinz Noricum. Alpha-Omega Reihe A., Bd. 262, Hildesheim-Zürich-New York 2012.

Mattingly H., Coins of the Roman Empire in the British Museum, vol. 4, Antonius Pius to Commodus, London 1940.

Migliorati G., Iscrizioni per la ricostruzione storica dell'impero romano da Marco Aurelio a Commodo, Milano 2011.

Paulus Orosius, Historiarum adversum paganos lib. VII, ed. C. Zangemeister, Lipsiae 1889.

Scriptores Historiae Augustae ab Hadriano ad Numerianum / The Scriptores Historiae Augustae, ed. T.E. Page, 3 vols., LCL, Cambridge-London 1924-1932.

$\mathrm{PIR}^{1}=$ Prosopographia Imperii Romani, saeculi 1.2.3., ediderunt E. Klebs, H. Dessau, P. de Rohden, I-III, Berolini 1897-1898.

$\mathrm{PIR}^{2}=$ Prosopographia Imperii Romani, saeculi 1.2.3., iteratis curis ediderunt E. Groag, A. Stein, L. Petersen, K. Wachtel, M. Heil, K.-P. Johne, L. Vidman, W. Eck, J. Heinrichs, adivvantibus M. Horster, A. Krieckhaus, A. Strobach, I-VIII, Berolini-Lipsiae 1933-2015.

Piso I., Fasti Provinciae Dacie I, Die senatorischen Amtsträger, Bonn 1993.

Piso I., Fasti Provinciae Dacie II. Die ritterlichen Amtsträger, Bonn 2013.

Seneca Lucius Annaeus, De beneficiis libri VII et de clementia libri II, ed. C. Hosius, Lipsiae 1900. 
Sextus Iulius Frontinus, Strategemata / Frontinus, The Stratagems and the Aqueducts of Rome, ed. M.B. McElwain, LCL, London-New York 1925 / Frontyn, Podstepy wojenne, transl. B. Burliga, Wrocław 2016 (Biblioteka Antyczna).

Titus Livius, Ab Urbe condita libri, ed. G. Weissenborn-M. Müller: libri 1-5, 6-10, 21-23, 24-26, 27-30, 31-34, 35-38, 39-42, 43-45, Periochae omnium librorum, Berlin 1880-1881/ Livy, History of Rome, transl. B.O. Foster, F.G. Moore, E.T. Sage, A.C. Schlesinger, vol. 1-14, LCL, Cambridge 1919-1959.

Wierschowski L., Fremde in Gallien-'Gallier' in der Fremde. Die Epigraphisch Bezeugte Mobilität in von und nach Gallien vom 1. bis 3. JH.N.CHR (Texte-Übersetzungen-Kommentare), Stuttgart 2001.

\section{Studies}

Abascal Palazón J.M., Los cognomina de parentesco en la Península Ibérica. A propósito del influjo romanizador en la onomástica, 'Lucentum' 1984, 3.

Alföldy G., Die Legionslegaten der römischen Rheinarmeen, Köln 1967 (Epigraphische Studien 3).

Alföldy G., Bellum desertorum, 'Bonner Jahrbücher' 1971, 171.

Alföldy G., Historia społeczna starożytnego Rzymu, Poznań 1991.

Amielańczyk K., Rzymskie prawo karne w reskryptach cesarza Hadriana, Lublin 2006.

Amielańczyk K., Crimina legitima w rzymskim prawie publicznym, Lublin 2013.

Ardevan R., Nochmals über interfecti a latronibus in Dakien, in: Studia Historica et Archaeologica in honorem Magistrae Doina Benea, Timişoara 2004.

Barnes T.D., The Sources of the Historia Augusta, Bruxelles 1978.

Berger A., Encyclopedic Dictionary of Roman Law, Philadelphia 1953.

Bekker-Nielsen T., Herodian on Greek and Roman Failings, in: Roman Rule in Greek and Latin Writing. Double Vision, eds. J.M. Madsen, R. Rees, Leiden-Boston 2014.

Bérard F., L'armée romaine à Lyon, Rome 2015.

Birley A.R., Marcus Aurelius, Boston 1966.

Birley A.R., The people of Roman Britain, London 1979.

Birley A.R., The Fasti of Roman Britain, Oxford 1981.

Birley A.R., The Roman Government of Britain, Oxford 2005.

Birley A.R., Hadrian to the Antonines, in: The Cambridge Ancient History, vol. XI, eds. A. K. Bowman et al., Cambridge 2000.

Birley A.R., Septimius Severus. The African Emperor, London-New York 2002.

Bost J.-P., Onomastique et société dans la cité des Pétrucores, in: Noms, identités culturelles et romanisation sous le Haut-Empire, eds. M. Dondin-Payre, M.-Th. Raepsaet-Charlier, Bruxelles 2001.

Brand C.E., Roman Military Law, London 1968.

Buonopane A., Inter vias latrones sum passus (CIL VIII 2728, 18122): morire lungo le strade romane / Inter vias latrones sum passus (CIL VIII 2728, 18122): dying on Roman roads, in: Statio amoena. Sostare e vivere lungo le strade romane, eds. P. Basso, E. Zanini, Oxford 2016.

Cheesman G.L., The Auxilia of the Roman Imperial Army, Chicago 1914.

Christol M., Deneux C., La latinisation de l'anthroponymie dans la cité de Nîmes à l'époque impériale (début de la seconde moitié du Ier siècle av. J.-C.-III er siècle ap. J.-C.): les données de la dénomination pérégrine, in: Noms, identités culturelles et romanisation sous le Haut-Empire, eds. M. Dondin-Payre, M.-Th. Raepsaet-Charlier, Bruxelles 2001.

Ciobanu R., Vie urbaine et délinquance le cas des 'latrones', in: Amoenitas urbium. Les agréments de la vie urbaine en Gaule romaine et dans les region svoisines, Caesarodunum tome XXXVXXXVI, eds. R. Bedon, N. Dupré, Limoges 2002.

Curchin L.A., The Romanization of Central Spain: Complexity, Diversity and Change in a Provincial Hinterland, London-New York 2004. 
Cook J.G., Crucifixion in the Mediterranean World, Tübingen 2014.

Cosme P., Le châtiment des déserteurs dans l'armée romaine, 'Revue historique de droit français et étranger' 2003, 81.

Crook J., Consilium Principis: Imperial Councils and Counsellors from Augustus to Diocletian, Cambridge 1955.

Cuomo S., A Roman Engineer's Tales, 'Journal of Roman Studies' 2011, 101.

Cupcea G., On Police and Administrative Duties of the Roman Military: Regionarii, 'Acta Musei Napocensis' 2016, 53, 1.

Dean L.R., A Study of Cognomina of Soldiers in the Roman Legions, Princeton 1916.

Demougin S., Les vétérans dans la Gaule Belgique et la Germanie inférieure, in: Cités, municipes, colonies. Le processus de municipalisation en Gaule et en Germanie sous le Haut-Empire romain, eds. M. Dondin-Payre, M.-Th. Raepsaet-Charlier, Paris 1999.

Dondin-Payre M., L'onomastique dans les cités de Gaule centrale (Bituriges Cubes, Éduens, Senons, Carnutes, Turons, Parisii), in: Noms, identités culturelles et romanisation sous le Haut-Empire, eds. M. Dondin-Payre, M.-Th. Raepsaet-Charlier, Bruxelles 2001.

Ehmig U., Subjektive und faktische Risiken. Votivgründe und Todesursachen in lateinischen Inschriften als Beispiele für Nachrichtenauswahl in der römischen Kaiserzeit, 'Chiron' 2013, 43.

Esmonde-Cleary S., Rome in the Pyrenees. Lugdunum and the Convenae from the first century B.C. to the seventh century A.D., London-New York 2008.

Forier S., Les anthroponymes formés sur des noms d'animaux en Gaule Narbonnaise et dans les provinces alpines, in: Noms, identités culturelles et romanisation sous le Haut-Empire, eds. M. Dondin-Payre, M.-Th. Raepsaet-Charlier, Bruxelles 2001.

Forni G., Il reclutamento delle legioni da Augusto a Diocleziano, Roma 1953.

Frei-Stolba R., Bielman A., Lieb H., Recherches sur les institutions de Nyon, Augst et Avenches, in: Cités, municipes, colonies. Le processus de municipalisation en Gaule et en Germanie sous le Haut-Empire romain, eds. M. Dondin-Payre, M.-Th. Raepsaet-Charlier, Paris 1999.

Fuhrmann Ch., Policing the Roman Empire: Soldiers, Administration, and Public Order, Oxford 2012.

Garnsey P., Social Status and Legal Privilege in the Roman Empire, Oxford 1970.

Găzdac C., Monetary Circulation in Dacia and the Provinces from the Middle and Lower Danube from Trajan to Constantine I (AD 106-337), Cluj-Napoca 2010.

Galimberti A., Erodiano e Commodo. Traduzione e commento storico al primo libro della «Storia dell'Impero dopo Marco», Gottingen 2014.

Gayet F., Les unités auxiliaires gauloises sous le Haut-Empire Romain, 'Historia' 2006, 55, 1.

Giuffrè V., La letteratura "de re militari", in: V. Giuffrè, Letture e ricerche sulla 'Res militaris', vol. 2, Napoli 1996.

Giuffrè V., Su Arrio Menandro, in: V. Giuffrè, Letture e ricerche sulla 'Res militaris', vol. 2, Napoli 1996.

Giuffrè V., Testimonianze sul trattamento penale dei milites, Neapel 1989.

Gregori G.L., Un nuovo senatore dell'età di Commodo?, 'Zeitschrift für Papyrologie und Epigraphik' 1995, 106.

Grünewald T., Bandits in the Roman Empire. Myth and Reality, London-New York 2004.

Gueye M., Délits et peines militaires à Rome sous la République: desertio et transfugium pendant les guerres civiles, 'Gerion' 2013, 31.

Hammond M., Septimius Severus, Roman Bureaucrat, 'Harvard Studies in Classical Philolo-

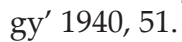

Hatt J.-J., Le passé romain de Strasbourg, ‘Gallia' 1949, 7, 2.

Hatt J.-J., Argentorate. Strasbourg, Lyon 1993.

Hengel M., Crucifixion in the Ancient World and the Folly of the Message of the Cross, Philadelphia 1977. 
Hekster O.J., Commodus. An Emperor at the Crossroads, Amsterdam 2002.

Honoré T., Ulpian Pioneer of Human Rights, Oxford 2002.

Kajanto I., Latin Cognomina, Helsinki 1965.

Kienast D., Römische Kaisertabelle, Darmstadt 1990.

Klotz A., Caius Iulius Caesar, in: Real-Encyclopädie der klassischen Altertumswissenschaft, X.1 (1918).

Kolb A., Communications and Mobility in the Roman Empire, in: Oxford Handbook of Roman Epigraphy, eds. C. Bruun, J. Edmondson, Oxford 2014.

Kubitschek J.W., Imperium Romanum. Tributim Discriptum, Praga-Lipsk 1889.

Kuleczka G., Studia nad rzymskim wojskowym prawem karnym, Poznań 1974.

Kutzmann W., Dezercja i samowolne oddalenie się w rzymskim wojskowym prawie karnym epoki pryncypatu, 'Wojskowy Przegląd Prawniczy' 1981, 36, 4.

Lazzaro L., Esclaves et affranchis en Belgique et Germanies romaines d'après les sources épigraphiques, Paris 1993.

Lamoine L., Le pouvoir local en Gaule romaine, Clermont-Ferrand 2009.

Linderski J., Caelum arsit and obsidione liberare: Latin Idiom and the Exploits of the Eighth Augustan Legion at the Time of Commodus, 'Zeitschrift für Papyrologie und Epigraphik' 2003, 142.

Le Bohec Y., The Imperial Roman Army, London 2000.

Le Roux P., L'armée romaine et l'organisation des provinces ibériques d'Auguste à l'invasion de 409, Paris 1982.

Łuć I., Disciplina militaris-charakter relacji między rzymskim dowódca a żotnierzami, in: Romanitas E Christianitas. Stanislao Płodzień (1913-1962) in memoriam, eds. A. Dębiński, S. Jóźwiak, Lublin 2008.

Łuć I.A., Boni et mali milites Romani. Relacje między żotnierzami wojsk rzymskich w okresie Wczesnego Cesarstwa, Kraków 2010.

Łuć I., Kary i środki represyjne w rzymskim sądownictwie wojskowym okresu republiki, in: Przemoc w świecie starożytnym. Źródła, struktura, interpretacja, eds. D. Słapek, I. Łuć, Lublin 2017.

Łuć I., Wojna Gn. Pompejusza z piratami, in: Gnejusz Pompejusz Wielki (106-48 przed Chrystusem) / Wybitni Rzymianie czasów schyłku Republiki, ed. N. Rogosz, Katowice 2018.

Łuć I., Archeologia wojny na wyniszczenie. Wojna galilejska Wespazjana i Tytusa (maj-listopad 67 roku naszej ery), 'Ethos' 2018, 31, 2 (122) 'Krzywda'.

Hammond M., Septimius Severus, Roman Bureaucrat, 'Harvard Studies in Classical Philology' 1940, 51.

MacMullen R., Soldier and Civilian in the Later Roman Empire, Cambridge 1963.

Millar F., A Study of Cassius Dio, Oxford 1964.

Millar F., The Emperor in the Roman World (31 BC-AD 337), London 1977.

Molinier-Arbo A., Les documents d'archives dans la Vita Commodi: degré zéro de l'histoire ou fiction?, 'Dialogues d'histoire ancienne', Supplément no. 4.1, 2010.

Navarro Caballero M., Gorrochategui J., Vallejo Ruiz M.J., L'onomastique celtibere: de la denomination indigene a la denomination romaine, in: Les noms de personnes dans l'Empire romain. Transformations, adaptation, évolution, ed. M. Dondin-Payre, Bordeaux 2011.

Nelis-Clément J., Les stationes comme espace et transmission du pouvoir, in: Herrschaftsstrukturen und Herrschaftspraxis Konzepte, Prinzipien und Strategien der Administration im römischen Kaiserreich, ed. A. Kolb, Berlin 2006.

Oliver J.H., Three Attic Inscriptions concerning the Emperor Commodus, 'The American Journal of Philology' 1950, 71, 2.

Pekáry Th., Seditio. Unruhen und Revolten im römischen Reich von Augustus bis Commodus, 'Ancient Society' 1987, 18.

Picard G.Ch., La révolte de Maternus, 'Bulletin de la Société Nationale des Antiquaires de France' 1985-1987. 
Picard G.Ch., Le vicus du Gué de Sciaux à Antigny (Vienne) en Poitou et son mini capitole, 'Bulletin de la Société Nationale des Antiquaires de France' 1992-1994.

Picard G., La romanisation de la Gaule problèmes et perspectives, 'Revue Archéologique', Nouvelle Série, Fasc. 2, 1993.

Reddé M., Legio VIII Augusta, in: Les légions de Rome sous le Haut-Empire, ed. Y. Le Bohec, Lyon 2000.

Rémy B., La dénomination des Viennois à l'époque impériale, in: Noms, identités culturelles et romanisation sous le Haut-Empire, eds. M. Dondin-Payre, M.-Th. Raepsaet-Charlier, Bruxelles 2001.

Reuter M., Legio XXX Ulpia Victrix. Ihre Geschichte, ihre Soldaten, ihre Denkmäler, Darmstadt/ Mainz 2012, (Xantener Berichte, Band 23).

Ricci C., Security in Roman Times: Rome, Italy and the Emperors, London-New York 2018.

Richardson, J.S., The Romans in Spain, Cambridge 1996.

Richier O., Centuriones ad Rhenum. Les centurions légionnaires des armées romaines du Rhin, Paris 2004.

Rosenberger V., Bella et expeditiones. Die antike Terminologie der Kriege Roms, Stuttgart 1992.

Rostovtzeff M., The Social and Economic History of the Roman Empire, 2 vols., Oxford 1957.

Sablayrolles R., Libertinus miles. Les cohortes de vigiles, Rome 1996.

Salway B., What's in a Name? A Survey of Roman Onomastic Practice from c. 700 B.C. to A.D. 700, 'The Journal of Roman Studies' 1994, 84.

Schiller A.A., Sententiae Hadriani de re militari, in: Sein und Werden im Recht: Festgabe für Ulrich von Lübtow, ed. von W.G. Becker, Berlin 1970.

Shaw B.D., Bandits in the Roman Empire, 'Past \& Present' 1984, $105=$ Studies in Ancient Greek and Roman Society, ed. R. Osborne, Cambridge 2004 = Rozbójnik, in: Człowiek Rzymu, ed. A. Giardin, Warszawa 1997.

Sidebottom H., The Date of the Composition of Herodian's History, 'L'antiquité classique' 1997, 66.

Spaul J., ALA'2. The Auxiliary Cavalry Units of the Pre-Diocletianic Imperial Roman Army, Andover 1994.

Spaul J., COHORS2. The Evidence for and a Short History of the Auxiliary Infantry Units of the Imperial Roman Army, Oxford 2000.

Stephano H., Thesaurus Graecae Linguae, vol. 7, Parisiis 1848-1854.

Stein A., Maternus, in: Real-Encyclopädie der klassischen Altertumswissenschaft, XIV.2 (1930).

Sztajerman H., Społeczeństwo zachodniorzymskie w III wieku, Warszawa 1960.

Syme R., Fiction about Roman Jurists, 'Zeitschrift der Savigny-Stiftung für Rechtsgeschichte' 1980, 97 = R. Syme, Roman Papers, ed. A.R. Birley, vol. 3, Oxford 1984.

Thompson E.A., Peasant Revolts in Late Roman Gaul and Spain, 'Past \& Present' 1952, 2.

Varga R., Pázsint A., The reflection of personal and collective tragedies in ancient sources. 1. Personal tragedies in Roman epigraphy, 'Journal of Ancient History and Archaeology' 2018, 5, 4 .

Varhelyi Z., The Religion of Senators in the Roman Empire. Power and the Beyond, Cambridge 2010.

Wipszycka E., Herodian, in: Vademecum historyka starożytnej Grecji i Rzymu. Źródłoznawstwo starożytności klasycznej, ed. E. Wipszycka, vol. 1-2, Warszawa 2001. 


\section{STRESZCZENIE}

Przestępcza działalność Maternusa, uciekiniera z armii rzymskiej, któremu udało się zebrać wokół siebie liczną grupę ludzi wykluczonych poza nawias prawa, uległa przeobrażeniu w otwarty bunt, który był wymierzony w Kommodusa. W niniejszym tekście została nakreślona rekonstrukcja okoliczności, które towarzyszyły formalnemu przekwalifikowaniu dezerterów i pospolitych bandytów we 'wrogów Rzymu'. Przeanalizowanie przebiegu tych wydarzeń nie byłoby możliwe bez uwzględniania źródeł literackich, epigraficznych, jak i tych z zakresu prawa rzymskiego. Jedynie uwzględnienie wszystkich dostępnych świadectw łączących się z tym zagadnieniem daje szansę, aby poddać go krytycznej i wieloaspektowej analizie. Bez takiego podejścia nie byłoby też możliwe zweryfikowanie obowiązującego w tym zakresie stanu wiedzy i zaproponowanie nieco odmiennej interpretacji.

Słowa kluczowe: Kommodus, Maternus, dezerterzy, bunt, wojna, żołnierze armii rzymskiej

\section{ABOUT THE AUTHOR}

Ireneusz Łuć - a historian employed in the Department of Ancient and Medieval History at the Institute of History in the Maria Curie-Skłodowska University in Lublin. He specialises in military and social history of ancient Rome. The areas of his research interests are epigraphy, numismatics, and Roman law. He is the author of academic articles and monographs, i.e. Oddziaty pretorianów w starożytnym Rzymie: rekrutacja, struktura, organizacja (Lublin 2004), Excubiae principis. Geneza i zadania żotnierzy kohort pretoriańskich w starożytnym Rzymie (Poznań 2010), and Boni et mali milites Romani. Relacje między żotnierzami wojsk rzymskich w okresie wczesnego cesarstwa (Kraków 2010). Co-author of translation, introduction and commentary, together with K. Królczyk, on Pseudo-Hyginus' On Setting Military Camps, Poznań 2010 (Fontes Historiae Antiquae). He is a co-editor of collective volumes, together with D. Słapek, Lucius Cornelius Sulla. History and Tradition (Lublin 2013), Marcus Antonius. History and Tradition (Lublin 2016) and Przemoc w świecie starożytnym. Źródta, struktura, interpretacje (Lublin 2017). A holder of the Scholarship of Fundacja Lanckorońskich (PAU in Krakow) and the Director of Academic Grant of the Ministry of Science and Higher Education in Warsaw and Academic Grant of National Science Centre in Krakow. 